Ministerstwo Nauki

i Szkolnictwa Wyższego

Digitalizacja archiwalnych numerów czasopisma naukowego Analecta Cracoviensia 1-24 (1969-1992)

i ich publikacja w otwartym dostępie - zadanie finansowane w ramach umowy 672/P-DUN/2017 ze środków

Ministra Nauki i Szkolnictwa Wyższego przeznaczonych na działalność upowszechniającą naukę

\title{
METODOLOGICZNE PODSTAWY ETYKI SEKSUALNEJ *
}

Niemal z dnia na dzień rośnie zainteresowanie etyką seksualną. Przejawem tego jest ogromna ilość publikacji poświęconych tej problematyce, prócz tego daje się zauważyć ciągłe poszerzanie się zakresu dy'skutowanych zagadnień. Od spraw szczegółowych tematyka dyskusji przesu-nęła się zdecydowanie w stronę ich antropologicznych założeń. Normy postępowania rozpatruje się w świetle ogólnej teorii miłości i płciowości, co z kolei zmusza do szerszego uwzględnienia pojęcia człowieka i twórczych sił moralności. Ostatnim niejako krokiem na tej drodze są wreszcie pytania tyczące metaetycznych aspektów etyki seksualnej oraz jej relacji do innych nauk seksuologicznych. W gruncie rzeczy wykraczają one poza granice ściśle rozumianej etyki seksualnej, ponieważ sięgają do pierwszych pojęć odnoszących się do całej etyki w ogóle jako filozofii moralności. Ale też te właśnie momenty ukazują równocześnie ich decydujące znaczenie dla rozbudowania normatywnej konstrukcji etyki seksualnej. Teoretyczna jakość tej etyki pozostaje w prostej zależności od sprawności narzędzi użytych przy jej konstruowaniu. Jasno zarysowana świadomość metodologiczna stanowi przeto jeden $\mathrm{z}$ warunków poprawności wypracowanych przy jej pomocy tez i uzasadnień. Racja ta tłumaczy, dlaczego przedmiotem naszych rozważań staną się zagadnienia metodologicznych podstaw etyki seksualnej, wśród których na pierwsze miejsce wysuwa się problem jej naukowego charakteru.

\section{NAUKOWY STATUS ETYKI SEKSUALNEJ}

Złożoność zagadnienia nie pozwala na to, aby jego istotny sens wyjaśnić za pomocą krótkiej, a równocześnie trafnie ułożonej formuły. Trzeba do tego pewnego wprowadzenia. Jak się zdaje, najlepiej się do tego nadaje zarysowanie niektórych charakterystycznych poglądów wypowiedzianych w tej sprawie.

* Artykuł ten jest zmodyfikowaną wersją jednego z rozdziałów większego opracowania poświęcego problematyce przedmałżeńskiej etyki seksualnej. 
Moralista szwajcarski Jakob David poruszył problem naukowego statusu etyki seksualnej w ramach obszerniejszego pytania: skąd współczesna etyka seksualna czerpie normy moralne. Odrzuciwszy autorytety religijne poświęca nieco uwagi „etyce naturalnej”, zwanej przez niego także ,etyką prawa naturalnego" ${ }^{1}$. Kontekst dowodzi, że chodzi mu o filozoficzną etykę normatywną opartą na rozumowych podstawach i głoszącą normy niezmienne i powszechnie ważne. Koronnym argumentem, jaki przeciwko tej etyce wytacza, jest zmienność natury ludzkiej. Mając tę zmienność przed oczyma stawia nad etyką naturalną tak wielkie znaki zapytania, że równają się one jej odrzuceniu. Autor nie widzi też innych możliwości zbudowania rozumowo uzasadnionej i metodologicznie odrębnej normatywnej etyki seksualnej. Stąd wniosek: „Tu mają głos nauki doświadczalne" 2. Dopełniając zaś później swoją myśl dodaje: „Według naszego przekonania jest tu... miejsce tylko dla filozofującego i antropologizującego etyka, który uprawia naukę świecką"3. W konkluzji można stwierdzić: zdaniem Davida reguły postępowania człowieka w sferze życia seksualnego ustalać winny nauki doświadazalne. Etyka w najlepszym wypadku może występować w roli tłumacza i przekaziciela ustaleń nauk doświadczalnych nadając im postać normatywnie sformułowanych sugestii i zachęt moralnych.

Podobny pogląd reprezentuje na terenie polskim Kazimierz Imieliński. Również jego zdaniem ,tworzenie racjonalnych norm zachowania seksualnego człowieka" możliwe jest tylko na gruncie ,faktów naukowych" ". Dzieje się tak dlatego, że „mechanizmy psychofizjologiczne w pośredni sposób wpływają... na tworzenie norm moralnych, obyczajowych i prawnych" " ${ }^{5}$. Nieco dalej zaś pisze: „Zrozumiałe jest, że wszelka nadbudowę normatywną dotyczącą ludzkiego zachowania seksualnego należy tworzyć na podstawie rzeczowych, naukowo sprawdzonych in-

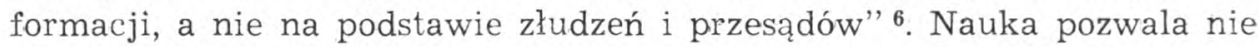
tylko zbudować racjonalną konstrukcję norm obowiązujących, ale umożliwia również wykrycie anachronistycznych elementów w normach tradycyjnie dziedziczonych i ich wyeliminowanie ze świadomości moralnej społeczeństwa ${ }^{7}$.

W omawianej pracy Imieliński nie pokusił się o to, aby postawioną tezę zilustrować przynajmniej typowymi przykładami, ukazującymi,

1 J. David, Christliche Sexualmoral in einer säcularisierten Welt, w: Sexualität ohne Tabu und christliche Moral, München-Mainz 1970, 26.

2 Dz. cyt., $27-28$.

3 Dz. cyt., 28.

${ }^{4}$ K. Imieliński, Psychofizjologiczne problemy seksuologii, w: Seksuologia spoleczna, pod red. K. Imielińskiego, Warszawa 1974, 11.

• Imieliński, Psychofizjologiczne problemy..., 12.

6 Tamże.

7 Dz. cyt., $12-13$. 
które normy moralne i dlaczego stanowią wytwór naukowo ustalonych danych psychofizjologii seksualnej, które zaś zostały przez te dane zakwestionowane jako anachroniczne. Jednakowoż $\mathrm{z}$ toku jego rozważań w książce pt. Życie seksualne. Psychohigiena ${ }^{8}$ można przypuszczać, że rolę tego rodzaju ,normotwórczych" sformułowań pełnią zdania, które stwierdzając określone prawidłowości psychofizjologiczne stwarzają podstawy dla usankcjonowania odpowiednich zachowań. Do takiego wniosku uprawniają np. wywody autora na temat wstrzemięźliwości płciowej ${ }^{9}$, poli- czy monogamicznej natury popędu seksualnego ${ }^{\mathbf{1 0}}$, a także uwagi poświęcone konfrontacji dotychczasowych poglądów z nowszymi badaniami naukowymi 11. Ogólnie mówiąc w kierunku usprawiedliwienia określonych zachowań oddziaływać powinno wszysłko, co biologicznie prawidłowe, co z biologicznego punktu widzenia pożyteczne, a równocześnie nie pozostające w otwartym konflikcie ze społecznymi normami postępowania, mającymi na oku przede wszystkim dobro zbiorowe ${ }^{12}$.

David i Imieliński reprezentują więc bardzo dziś rozpowszechnione stanowisko, które a limine odrzuca możliwość i potrzebę istnienia odrębnej etyki seksualnej jako, nauki filozoficznej i normatywnej. W podtekście tego stanowiska kryje się założenie, że jedynym normotwórczym organem jest ,nauka”, gdyż opiera się na ,rzeczowych”, „obiektywnie sprawdzonych" informacjach. Miano zaś nauki we właściwym tego słowa znaczeniu przysługuje wyłącznie naukom doświadczalnym. A zatem etyka seksualna ukształtowana na wzór innego modelu aniżeli model nauk doświadczalnych, ,nauką" nie jest i być nie może, z czego wypływa ostateczny wniosek, że nie jest zdolna do formułowania norm postępowania ważnych w zakresie życia seksualnego.

Z innym podejściem do tego samego zagadnienia można się spotkać u francuskiego pisarza Charles'a Antoine’a oraz Mikołaja Kozakiewicza. Godzą się oni, że nie ma i być nie może naukowej etyki seksualnej. Ran-ga naukowości przysługuje wyłącznie naukom doświadczalnym ze względu na ich zdolność obiektywnego badania i sprawdzalnego uzasadniania swych twierdzeń. Inaczej ma się sprawa z etyką seksualną. Swoje ideowe podstawy zakłada ona ,na określonej wizji człowieka, na określonej koncepcji filozoficznej i moralnej, wreszcie na kulturowej tradycji danego narodu" 13. Tego rodzaju założenia nie wystarczają do przekształcenia

\footnotetext{
8 K. Imieliński, Życie seksualne. Psychohigiena, Warszawa $1969^{3}$.

9 Dz. cyt., 259-263; por. 255-256.

10. Psychofizjologiczne problemy..., 28-37.

11 Dz. cyt., $37-43$.

12: W podobnych kategoriach myślenia mieszcza się także wywody H. Malewskiej w książce: Kulturowe $i$ psychospoteczne determinanty życia seksualnego, Warszawa 1967.

${ }_{13}$ M. Kozakiewicz, Moralne aspekty wychowania seksualnego, w: Seksuologia społeczna, 270; por. Ch. Antoine, Sens płciowości i poszukiwanie etyki, w: Natura, kultura, płeć, tłum. K. Łopuska, Kraków 1969, 272.
} 
etyki seksualnej w naukę, gdyż wypływają ze zgoła innych pozanaukowych źródeł. Stanowią one efekt subiektywnych i irracjonalnych wyborów uniemożliwiających stosowanie naukowych kryteriów obiektywności i sprawdzalności ${ }^{14}$. Ale to sprawy nie kończy. Nauki doświadczalne bowiem przy całym swoim obiektywizmie nie dysponują możliwościami formułowania norm moralnych, gdyż ,to, co... jest wydedukowane $\mathrm{z}$ danych przyrodniczych lub empirycznych danych nauk społecznych, jest najmniej ważne i odnosi się tylko do warstwy informacyjnej wychowania seksualnego, ...to zaś, co w nim jest naprawdę ważne i decyduje o właściwym wychowaniu ludzi... nie ma i nie może być wydedukowane z danych nauk przyrodniczych ani innych nauk empirycznych" ${ }^{15}$. Kapitalne zatem dla pedagogiki zadanie formułowania norm moralnych wymaga osobnej, do tego właśnie celu powołanej dyscypliny. Kozakiewicz za taką właśnie dyscyplinę uważa etykę seksualną jako specyficzna zgoła „wiedzę" czy „doktrynę” filozoficzno-normatywną, nie będącą „nauką" we właściwym tego słowa znaczeniu, ale czyniącą zadość bardzo istotnemu zapotrzebowaniu społecznemu i pedagogicznemu.

Mamy zatem dwa odmienne spojrzenia na stosunek etyki seksualnej do nauk doświadczalnych. Punktem zbieżnym jest negacja naukowego statusu etyki seksualnej. Ale $\mathrm{w}$ myśl jednego $\mathrm{z}$ tych poglądów etyka seksualna nie ma $\mathrm{w}$ ogóle racji bytu, a więc nawet $\mathrm{w}$ charakterze pseudonauki filozoficznej mającej za zadanie formuławanie norm moralnych ważnych w seksualnych zachowaniach człowieka, podczas gdy drugi pogląd przyznaje jej takie właśnie zadanie. Jednakowoż pełnienie tego zadania uważa za funkcję pozanaukową, w związku z czym odmawia etyce miana nauki widząc w niej tylko przejaw i konsekwencję irracjonalnej ideologii. Nie trzeba też zbyt rozległej wiedzy z zakresu historii etyki, aby $w$ poglądach tych dostrzec ogólną tezę jednego ze współczesnych kierunków metaetycznych, która głosi, że w ogóle wszelka etyka normatywna nauką nie jest i być nie może. Stanowisko omówionych autorów jest jedynie aplikacją tej ogólnej tezy do problematyki etyki seksualnej.

$\mathrm{Na}$ tle zreferowanych stanowisk nie trudno już zdać sobie sprawę, na czym polega istotny sens pytania o naukowy status etyki seksualnej. Da się on wyrazić następująco: czy faktycznie nauki szczegółowe, a nie etyka seksualna, są powołane do formułowania norm lub zaleceń dla seksualnych zachowań człowieka? Czy rzeczywiście przedmiot etyki seksuai-nej (a więc odnośne oceny i normy) jest taki, że z góry niejako uniemożliwia zbudowanie nauki normatywnej o treści obiektywnej i należycie uprawomocnionej? Na czym tedy polega i w czym się przejawia jej naukowy charakter, jeżeli taki wolno jej w ogóle przypisać?

14 Kozakiewicz, dz. cyt., 261.

15 Kozakiewicz, dz. cyt., 270. 
Odpowiedź na te pytania wymaga uprzedniego rozpatrzenia nie ty1ko poszczególnych twierdzeń, ale przede wszystkim metodologicznych założeń, na których świadomie lub podświadomie opierają się antagoniści normatywnej etytki seksualnej. Zacząć wypada od autorów opowiadających się za naukami szczegółowymi jako powołanymi do ustalania reguł postępowania seksualnego. Analiza odnośnych wypowiedzi wskazuje, że u podstaw rozumowania tych autorów leży dwojakie założenie, z których pierwsze nazwać można założeniem s cjentys ty c zny m, drugie natomiast założeniem $\mathrm{n}$ a t u ralis t y c z n y m.

Jak się przedstawia tok rozumowania inspirowanego założeniem scjentystycznym? Dla autorów reprezentujących ten typ myślenia za pewnik nie podlegający dyskusji uchodzi założenie, że tylko twierdzenia empiryczne mogą być uznane za twierdzenia naukowe, twierdzenia zaś naukowe sa nie tylko pewne i racjonalnie uzasadnione, ale ponadto - i tu kryje się istota rzeczy - są uniwersalnie prawomocne, czyli ważne. Na tej podstawie mogą być orzekane o wszystkich aspektach przedmiotu, który się mieści w zakresie ich badania. Wiszystkie inne twierdzenia muszą być do nich sprowadzone i przez nie sprawdzone, inaczej nie moge sobie rościć tytułu do poprawności i nie zasługują z tego powodu na racjonalną akceptację. W tym kierunku zorientowane są wyraźnie wyłwody Davida.

U podstaw myślenia scjentystycznego leży zatem zasada powszechnej ważności twierdzeń empirycznych. W wypadku założenia naturalistycznego podstawa ta ulega zmianie. Przyjmuje się tu bowiem, że przyroda jest zbudowana $z$ jednego tworzywa materialnego, a przeto sfera moralności podlega tym samym prawom, co pozostałe kategorie bytu. Co jest zatem w sferze psychofizjologicznej czy biologicznej ,,prawidłowe”, „pożyteczne”, „celowe”, to samo winno znaleźć należytą ocenę i zalecenie w ,normatywnej nadbudowie”, jak to określa Imieliński. Tego też autora wypada uznać za wyraziciela negacji etyki seksualnej opartej na założeniach naturalistycznych.

Jak się do tych dwu kierunków metodologicznych ustosunkować? Postaramy się wykazać - na razie również w formie najogólniejszych konstatacji - że wynikają one $\mathrm{z}$ pewnych fundamentalnych uproszczeń i nieścisłości, czy też apriorycznych i arbitralnych rozstrzygnięć.

Weźmy wpierw pod uwagę założenie scjentystyczne. Stwierdzić należy $\mathrm{z}$ całą stanowczością, że w imię elementarnego postulatu ścisłości obowiązującego nauki empiryczne zakres głoszonych przez nie twierdzeń nie może wykraczać poza granice doświadczenia zmysłowego zewnętrznego lub wewnętrznego. Moralność natomiast w postaci ocen i norm w żadnym wypadku pod to doświadczenie na podpada. Ilekroć zatem się zdarza, że dany uczony dokonuje przejścia od zdań empirycznych, np. biolo- 
gicznych, psychologicznych czy socjologicznych do zdań czy sugestii o charakterze normatywnym, zachodzi wówczas nieuprawnione na gruncie założeń scjentystycznych tworzenie zdań nowego typu, mianowicie filozoficznych, z poprzednimi logicznie nie związanych. Posługują się wymienionymi uprzednio przykładami można powiedzieć, że zdanie biologiczne, psychologiczne lub socjologiczne na podstawie utajonego założenia jego rzekomej powszechnej ważności zostaje przekształcone w zdanie biologistyczne, psychologistyczne czy sorjologistyczne. W ten sposób założenie scjentystyczne staje się w gruncie rzeczy błędem scjentystycznym.

Odnośnie założenia naturalistycznego podkreślić znowu wypada, że występująca w nim monistyczna teoria bytu jest nie do przyjęcia w świetle integralnej filozoficznej wizji człowieka. Zbyt ostro rysują się różnice między duchową stroną natury czlowieka a jej cielesnym podłożem, czego konsekwencją jest niesprowadzalność zjawisk moralnych na grunt przyrodniczy. Doceniają ten fakt również materialistycznie zorientowani niektórzy filozofowie marksistowscy, choćby cytowany już Kozakiewicz, z innych zaś M. Fritzhand, postulując autonomiczność etyki w stosunku do nauk szczegółowych przyrodniczych, a nawet historycznych, mimo że ostatecznych uwarunkowań moralności doszukują się W ekonomicznych strukturach społeczeństwa.

A zatem, zakładając nawet, że prawidłowość psychofizjologiczna zosteła poprawnie ustalona i nie budzi żadnyzh uzasadnianyzh wąi oliwośsi (co nie zawsze się zdarza), to jednak między tą prawidłowością a prawidłowością moralną, między użytecznością biologizzną lub społecznca a dobrem moralnym zachodzi istotna różnica. Podobieństwo słów, czy nawet pewnych zewnętrznych cech nie wystarczy absolutnie do zniwelowania tych różnic. Sprawy te zostaną bliżej naświetlone w toku systematycznego wykładu podstaw etyki seksualnej. Ale już to, co zostało dotąd powiedziane, skłania do przypuszczenia, że tylko bardzo zawężony punkt widzenia rzeczywistości ludzkiej skłonił Imielińskiego do stawiania tak apodyktycznych twierdzeń opartych na tak kruchych podsta-wach. I to jest racja, że również naturalistyczne założenia negacji etyki seksualnej trzeba w końcu uznać za zwykły błąd naturalistyczny.

Naświetlając powyższe uwagi od strony pozytywnej warto przyprzymnieć słuszną uwagę Kozakiewicza, że rola nauk szczegółowych w zakresie seksualnych zachowań człowieka ogranicza się wyłącznie do opracowania ,informacyjnej warstwy” o tym przedmiosie. Dalej już nie sięga. Jeżeli zaś sięga, to tylko za cenę któregoś z dwu omówionych błędów. Na gruncie zaś etyki pogląd Kozakiewicza znajduje swoje uzasadnienie w starej, od czasów Hume’a znanej zasadzie, w myśl której naweł z powszechnie obserwowanych zachowań ludzi nie można wnioskowac, 
że tak „być powinno" w znaczeniu oczywiście moralnym. W sferze zaś seksualnego życia człowieka zasada ta odnosi się nie tylko do zachowań ludzi, ale także do funkcjonowania mechanizmów czynnych w strukturze jego płciowości. Dlatego żadne osiąnnięcie psychofizjologii czy socjologii nie może mieć samo z siebie normatywnego znaczenia. Jeżeli je ma, to czerpie je z innego zupełnie źródła, które wykryć i normatywnie ukierunkować może tylko odrębna, na własnych podstawach oparta nauka, czyli etyka seksualna.

Zanim jednak to twierdzenie zostanie uznane za w pełni usprawiedli.. wione, trzeba jeszcze podjąc drugi wątek dyskusji nad naukowością etyki seksualnej i zając się sprawą obiektywnego charakteru i sprawdzalności formułowanych przez nią norm i ocen. Kozakiewicz, który wykazał tak dużą rezerwę przy omawianiu normotwórczych kompetencji nauk szczególowych, w tym punkcie idzie bez zastrzeżeń po linii pozytywi-stycznej koncepcji nauki. Jego zdaniem, jak wiadomo, nie tylko nauki szczególowe, ale również etyka seksualna nie jest zdolna zadość uczynić postulatowi rzeczowości i sprawdzalności w zakresie budowanego przez nią systemu norm i ocen, gdyż w tym zakresie w ogóle nie jest możliwe budowanie jakichkolwiek zdań naukowo ważnych, czyli rzeczowych w treści, a sprawdzalnych w uzasadnieniu. Pod tym względem etyka seksualna dzieli los całej filozofii i razem z nią opiera się na niesprawdzalnych subiektywnych wizjach człowieka, a nie, jak nauka, na faktach. Innymi słowy nauka buduje zdania rzeczowe i sprawdzalne, i dlatego nis jest powołana do tworzenia norm moralnych, natomiast etyka seksualna tworzy normy, ale znowu nie są to zdania naukowe.

Zarysowany tok rozumowania stawia nas wobec problemu, czy rzeczywiście etyka seksualna skazana jest z konieczności na subiektywizm i dowolność głoszonych przez siebie zdań normatywnych. Należy rozważyć dwie możliwości: jedna rozpatruje ten problem od strony subiektywnych dyspozycji badacza, niezbędnych do prawidłowego przeprowadzenia procesu poznawczego w zakresie etyki seksualnej, druga natomiast od strony przedmiotu badania.

M. Ossowska w swej książce Podstawy nauki o moralności ${ }^{16}$, rozróżnia dwie postawy: etyka i badacza moralności. Badacz interesuje się tylko faktami moralnymi i dlatego zajmuje on postawę obiektywną i rzeczową, etyk zaś głosi normy i tym samym kieruje się własnymi upodobaniami. Badacz prezentuje to, co stwierdził i co można udowolnić, etyk zaleca jako dobre i obowiązujące to, co jemu się wydaje jako dobre i obowiązujące. Koniec końców etyk narzuca swoje przekonania, ale ich nie uzasadnia.

16 M. Ossowska, Podstawy nauki o moralności, Warszawa $1966^{4}, 9-10$. 
Ten wywód Ossowskiej da się w całej rozciągłości zastosować do naszego tematu jako ilustracja stanowiska Antoine'a i Kozakiewicza, a zarazem dostarcza instruktywnego materiału do analizy krytycznej. Należy sprawdzić, czy rzeczywiście naukowcy pracujący na polu nauk szczegółowych znajdują się w lepszej sytuacji, aniżeli etycy. Czy ich pozycja naukowa jest taka, że stwarza maximum gwarancji przestrzegania rygorów obiektywizmu w realizowaniu właściwych sobie zadań badawczych, czy też można przytoczyć racje, które każą w to wątpić?

Wiadomo, że w zasięgu badania naukowego opartego na doświadzze-niu leży nie tylko stwierdzenie faktu, ale także jego interpretacja. Liczne przykłady dowodzą, że samo stwierdzenie faktu nie zawsze jest proste. Subiektywne dyspozycje badacza, jego uprzedzenia czy tendencje mogą poważnie zakłócić proces ustalania faktycznego stanu rzeczy i dać w wyniku jego zgoła zafałszowany obraz. Tym bardziej niebezpieczeństwo to wzmaga się $w$ toku interpretacji. W pewnych przynajmniej kontekstach, mianowicie tam, gdzie interpretacje faktów nie są obojętne dla ideologicznych przeświadczeń badaczy, jednym ze współczynników interpretacji stają się określone filozoficzne inspiracje, którymi powodują się oni niekiedy świadomie, niekiedy zaś nieświadomie. Nie wchodząc w to, czy tak być musi, a nawet czy tak jest zawsze, a wię: zakładając tylko. że dzieje się tak dosyć często, można żywić pewne zastrzeżenia co do obiektywności nauk szczegółowych. Postulat obiektywności badania naukowego rozpatrywany z tego punktu widzenia staje się postulatem ogólnonaukowym, odnoszącym się do wszelkich dyscyplin teoretycznych metodycznie uprawianych. Specjaliści z zakresu nauk szczegółowych nie znajdują się pod tym względem w sytuacji uprzywilejowanej. Innymi słowy, chociaż każdej nauce przyświeca ideał obiektywności i rzeczowości, to jednak każda może popaść w sidła i.złudzenia subiektywizmu i arbitralności. Dlatego tak wielką rolę dla prawidłowego rozwoju wszelkich w ogóle nauk pełni świadomość ich metodologicznego statusu oraz zdolność do krytycznej refleksji nad wynikami własnych i cudzych dociekań. Jest to niewątpliwie niezbędny czynnik dążenia ludzkiego umysłu do prawdy, jednakowo ważny w naukach szczegółowych, filozofii i etyce. Idzie tylko o to, aby zainteresowani w tych dziedzinach badacze chcieli dostrzec uniwersalny walor tego postulatu, szczególnie zaś tę jego konsekwencję, która w sformułowaniach naukowych każe wyodrębniać należycie treści „czysto” naukowe, empiryczne od filozoficznych. Niestosowanie się do tej wskazówki odbija się ujemnie zarówno na tzw. nauce, jak i filozofii.

Uwagi powyższe mimo wszystko nie dotykają istotnego nerwu sprawy. Kryje się on w drugim aspekcie zagadnienia naukowego statusu etyki seksualnej, który dotyczy przedmiotu badań etycznych w ogóle, w na- 
szym zaś wypadku właśnie etyki seksualnej. Idzie o to, czy możliwe jest naukowo obiektywne i sprawdzalne badanie zjawisk moralnych. Kozakiewicz, a z nim wielu innych autorów, zdecydowanie opowiada się za poglądem, że zjawiska moralne stanowią odrębną dziedzinę rzeczywistości, wymykającą się spod zasięgu narzędzi i metod, jakimi dysponuje współczesna nauka. Jest to bowiem świat norm i wartości, poddany logice serca, kulturowego etosu czy wreszcie gry sił i interesów gospodarczo-społecznych, w których nie ma miejsca na doświadczenie zewnętrzne, a tym samym na obiektywność i intersubiektywną sprawdzalność. Z drugiej strony dla życia i rozwoju ludzkiego jest to świat nader istotny. Wobec tego Kozakiewicz formułuje ostateczny wniosek: etyce seksualnej należy odmówić miana nauki na podstawie tej samej racji, w imię któ-rej nauce zaprzecza się prawa do wyrokowania o normach życia seksualnego. Etyka seksualna posiada odrębny status metodologiczny właściwy filozofii i ideologii. Nie prowadzi on wprawdzie do zbudowania twierdzeń obiektywnie, czyli doświadczalnie sprawdzalnych, wystarcza jednak do tworzenia ocen i norm moralnych.

Pogląd Kozakiewicza proponuje więc stworzenie dla doktryn filozoficznych specyficznego „,getta”, w obrębie którego znalazłoby się miejsce również dla etyki seksualnej. Linią graniczną oddzielająıą filozofię od świata nauki byłoby doświadczenie zewnętrzne. Jak daleko sięga to doświadezenie, można mówić o panowaniu nauki, gdzie zaś czynne są inne źródła poznawcze, zaczyna się królestwo filozofii i ideologii. W takim założeniu punkt ciężkości sporu o obiektywność naukową sprowadza się do rozstrzygnięcia, czy rzeczywiście jedynym źródłem rzeczowej, obiektywnej informacji o badanym przedmiocie jest doświadczenie zewnętrzne, czy nie mamy innych jeszcze dróg docierania do prawdy i na czym one polegają.

Dyskusja nad naukowym statusem etyki seksualnej nie jest mimo wszystko właściwym terenem dla szerszego rozwinięcia tego zagadnienia, gdyż ma ono charakter ogólnonaukowy, a problem etyki seksualnej jest tylko jego szczegółowym zastosowaniem. W tym stanie rzeczy ogran:czyć się wypada do podania fundamentalnych ustaleń wyznaczających punkty wyjścia i ostateczny rezultat odpowiedzi.

Wbrew częstemu w świecie naukowym mniemaniu związanie postulatu obiektywności i rzeczowości z doświadczeniem zewnętrznym nie stanowi ani empirycznie ustalonego pewnika, ani logicznie prawidłowo uzasadnionego wniosku. Doświadczenie zewnętrzne mówi bowiem tylko o przedmiocie ,doświadczanym”, nie zaś o sobie samym, o przysługującej mu ,obiektywności”. Co więcej, w tym właśnie momencie, w którym. zwróciłoby się ku sobie samemu, przestałoby być doświadczeniem ,,zewnętrznym". Również analiza treściowa pojęcia „obiektywności” nie 
uzasadnia wniosku, że cecha ta przysługuje wyłącznie doświadczeniu zewnętrznemu. Pojęcie to wyraża tylko tyle, że przedmiot poznania winien się znajdować w obrębie realnego świata dostępnego poznaniu człowieka i że poznanie to winno być adekwatne w stosunku do tego przedmiotu.

Skąd się bierze zasada, że z obiektywnym i rzeczowym poznaniem spotykamy się tylko na gruncie doświadczenia zewnętrznego? Odpowiedzi na to pytanie udziela filozofia. Z danych historycznych wynika, że chodzi tu o jedną ze szczegółowych tez empirycznej teorii poznania. Teoria ta od wieków zapuściła głębokie korzenie w filozofii europejskiej, ulegając z biegiem czasu różnym modyfikacjom, ale tė̇ i stałej rozbudowie. Za uprawnione przyjmuje ona wyłącznie zdania oparte na danych doświadezenia, przede wszystkim zewnętrznego, ponieważ to właśnie doświadczenie uważa za jedyne źródło poznania dostarczającego człowiekowi informacji o świecie realnym. W dalszych konsekwencjach posłużyła ona filozofom orientacji neopozytywistycznej i socjologistycznej za narzędzie teoretyczne do podważania naukowych podstaw etyki w ogóle, w naszym zaś wypadku etyki seksualnej. Na razie jedno zasługuje na podkreślenie: negacja naukowego charakteru etyki seksualnej w imię rzekomego braku obiektywności i rzeczowości w budowanych przez nią zdaniach normatywnych zrodziła się z wyraźnej inspiracji filozoficznej, a nie empirycznej. Nie chodzi tu zatem o konflikt między naukami empirycznymi a filozofią, ale o konflikt między dwiema filozofiami, dokładniej mówiąc między dwiema różnymi koncepcjami teoriopoznawczymi. To swoje filozoficzne znamię zachowuje ów konflikt nawet wtedy, gdy pojawia się na ustach przedstawicieli nauk szczególowych, obojętne, świadomych czy nieświadomych jego filozoficznego rodowodu. A zatem dyskusja nad zaktualizowaną tą drogą problematyką metodologiczną toczyć się winna na płaszczyźnie filozoficznej.

Jedną ze stron biorących w niej udział jest racjonalna teoria poznania. Przeciwstawia się ona empiryzmowi głosząc, że obok zmyłsłów i doświadczenia również rozum człowieka prowadzi do obiektywnego poznania rzeczywistości głównie dzięki zdolności docierania do istotowej struktury bytów. Tym samym kategoria przedmiotów poznania ulega znacznemu wzbogaceniu: obok przedmiotów doświadczenia zewnętrznego obejmuje ona przedmioty zmysłowego doświadczenia wewnętrznego, a wreszcie przedmioty poznania intelektualnego. W tym ostatnim zakresie znajduje swe miejsce moralność człowieka, na którą składają się oceny, normy i wzory osobowe rozumiane jako elementy składowe obiektywnego porządku moralnego, aczkolwiek odrębnego od świata rzeczy substancjalnych. Oczywiście różnorodność przedmiotów poznania pociąga za sobą zróżnicowanie źródeł i metod ich filozoficznego badania, a także kry- 
teriów sprawdzalności uzyskanych tą drogą zdań naukowych (postulat intersubiektywności pozostaje $\mathrm{w}$ zasadzie bez zmian). W związku z tym pojęcie nauki musi ulec odpowiedniemu wzbogaceniu, czego wynikiem będzie wyodrębnienie różnego rodzaju nauk oraz różnych stopni pewności budowanych przez nie systemów wiedzy. Wszystkie jednak uznać należy za części składowe nadrzędnej kategorii pojęciowej, której na imię jest "nauka”, jeżeli tylko spełniają wymagane $\mathrm{w}$ tym względzie kryteria. A to znaczy, że mają one stanowić logicznie uporządkowany zbiór zdań o odpowiednim przedmiocie wyrażonych w języku jednø.znacznie określonym, czyli intersubiektywnym, oraz uzasadnionych w sposób dostosowany do natury owego przedmiotu i w tych granicach sprawdzalnych.

W tak zakreślonych ramach pojęcia „nauki” mieszczą się nie tylko nauki przyrodnicze czy matematyczne, ale również nauki społeczne i humanistyczne, a także filozoficzne, w ich rzędzie również etyka seksualna jako szczegółowa część etyki filozoficznej. Jak z tego wynika, pojęcie nauki, jakim posługuje się Kozakiewicz przy konstruowaniu poglądu o pozanaukowym charakterze etyki seksualnej, jest zbyt ciasne i jednostronne. Urobione ono zostało pod presją neopozytywistycznych koncepcji nauki i wyrosłej na ich gruncie emotywistycznej negacji racjonalnego charakteru etyki. Można by jednak w tej sprawie pójść na pewien kompromis. Mianowicie gdyby się uznało za słuszny postulat, aby odmienność przedmiotu i metod badania, jaka charakteryzuje nauki szczegółowe i filozofię, znalazła swój wyraz i podkreślenie w dwu od-rębnych terminach „nauka” i „filozofia”, wówczas nic nie stoi na przeszkodzie, aby myślenie filozoficzne uznać za inne, niż „naukowe”, a więc za „pozanaukowe”. Tego tylko wystrzegać się należy, ażeby termin „filozofia”, ,filozoficzny” nie był synonimem tego, co „,dowolne”, ,subiektywne”, „niesprawdzalne”. Jego właściwy sens w tej konwencji oznacza „obiektywne i sprawdzalne”, aczkolwiek „w inny sposób”, aniżeli to ma miejsce w naukach szczegółowych.

Wywód na temat naukowego statusu etyki seksualnej był konieczny z dwojakiego powodu. Najpierw trzeba wziąć pod uwagę wysoki autorytet, jakim w opinii społecznej cieszy się dziś instytucja ,nauki". W tym stanie rzeczy określenie jakiejś dyscypliny jako „,nienaukowej" równa się w oczach przeciętnego człowieka jej dyskwalifikacji i radykalnemu zakwestionowaniu teoretycznej i praktycznej wartości głoszonych przez nią twierdzeń. Ponadto w świecie naukowym panuje na tym odcinku znaczne zamieszanie pojęć, spowodowane w głównej mierze silną pozycją, jaką w metodologii nauk wciąż jeszcze zajmuje pozytywizm i jemu właściwy styl myślenia.

Wbrew tym tendencjom należało podkreślić, że etyka seksualna ma 
rację bytu nie tylko jako funkcja określonej ideologii czy filozofii i jej właściwego obrazu człowieka. Etyka seksualna zasługuje na to, aby była uważana za dyscyplinę naukową względnie filozoficzno-naukową, bo jest zgodna $\mathrm{z}$ fundamentalnymi prawami prawidłowego logicznie i sprawdzalnego myślenia.

Jeżeli jednak tak ustawi się zagadnienie, to wówczas stwierdza się pośrednio, że w budowie etyki seksualnej występują wszystkie elementy, które są właściwie każdej nauce. Innymi słowy przyjmuje się, że etyka seksualna ma określony przedmiot, źródła i metodę badania. Wobec tego na kolejnym etapie naszych rozważań należy podjąć ten temat i rozwinąć jego poszczególne wątki. Spełnienie tego zadania nie tylko umożliwi głębsze spojrzenie na naukowy status etyki seksualnej, ale odsłoni także główne wiązania jego logicznej struktury.

\section{PRZEDMIOT, ŹRÓDEA I METODA ETYKI SEKSUALNEJ}

a) Przedmiot etyki seksualnej

Pojęcie przedmiotu jakiejkolwiek nauki ma nam ukazać tę dziedzinę rzeczywistości, której badaniem dana nauka się zajmuje. Ale rzeczywistość badana przez określone nauki jest zazwyczaj bardzo złożona, co zmusza do odpowiedniego zróżnicowania pojęcia jej przedmiotu. Filozofia wypracowała narzędzia teoretyczne potrzebne do wykonania tego zadania ${ }^{17}$. Korzystając $\mathrm{z}$ ich pomocy można ustalić podstawowe uściśle-nia w omawianej aktualnie materii.

Etyka seksualna musi w swoich badaniach mieć na uwadze całokształt elementów, do których należy najpierw właściwa ludzkim osobnikom płciowa struktura ich natury i przejawy jej funkcjonowania oraz uwarunkowana tą płciowością specyficzna, gatunkowo odrębna kategoria aktów ludzkich. W literaturze seksuologicznej akty te zwykło się określać za pomocą terminów „zachowania seksualne człowieka”, „działania seksualne" czy jeszcze innych podobnych. Jednakowoż aktami tymi i warunkującymi je strukturami biopsychicznymi etyka seksualna nie zajmuje się w taki sposób, w jaki czynią to nauki szczegółowe, przede wszystkim fizjologia i psychologia. Dla tych nauk jest to bezpośredni przedmiot ich zainteresowania. W zasięgu ich badań leży przeto biologiczno-anatomiczne podłoże płciowości człowieka, procesy fizjologiczne, towarzyszące im przeżycia psychologiczne, a także uwarukowania zewnętrzne seksualnego życia ludzkiego. Dla etyki seksualnej cały ten splot zjawisk ma znaczenie tylko pośrednie. W gruncie rzeczy stanowią one tylko dynamiczny substrat, na który nakłada się i w odniesieniu do

17 Por. T. Slipko, Zarys etyki ogólnej, Kraków 1974, 21. 
którego formuje się inna rzeczywistość, dla etyki seksualnej bardziej istotna i interesująca. Ten właśnie stan rzeczy sprawia, że akty te zwie się ,przedmiotem materialnym” etyki seksualnej.

Co stanowi dla etyki seksualnej tę ważną rzeczywistość, o tym mówi kolejny jej przedmiot, w nomenklaturze filozoficznej zwany ,przedmiotem formalnotreściowym". Obejmuje on ogół wartości, ocen i norm akceptowanych przez ludzi jako cenne dla nich i obowiązujące ich reguły postępowania w zakresie życia seksualnego, czyli tzw. potocznie moralność seksualną. Chodzi tu więc o to, co ludzie uważają za moralnie dobre lub złe, nakazane lub dopuszczalne względnie zakazane w tej dziedzinie, czyli o ich własne intuicje i przeświadczenia moralne.

Bardzo często tę właśnie moralność zawartą w świadomości ludzkiej nazywa się także ,etyką seksualną"..W naszym wszakże słownictwie sens tych dwu terminów będzie różny. „Etyka seksualna” służyć będzie do oznaczania filozoficznej refleksji normatywnej nad, ,moralnością seksualną", która zgodnie z podanym przed chwilą wyjaśnieniem wyrażać będzie funkcjonujący w świadomości ludzi zespół wartości i norm postępowania w życiu seksualnym.

Ten właśnie świat moralnych wartości i reguł normujących seksualne zachowania człowieka nie stanowi wyłącznej domeny etyki seksualnej, ponieważ należy on do przedmiotu badań jeszcze innych nauk, głównie psychologii, socjologii i etnologii. Każda z nich bowiem wynajduje w splocie zjawisk składających się na właściwą poszczególnym jednostkom i grupom moralność seksualną jakiś odmienny aspekt, o którym chce uzyskać naukowo sprawdzone informacje. Usiłują więc między innymi ustalić, jak się rozwijają pojęcia moralne ludzi, jakie na to wpływają czynniki, jakie mechanizmy określają indywidualny i społezzny stan pojęć moralnych, jakim podlegają one przeobrażeniom - oczywiście wszystko w odniesieniu do moralności seksualnej. Gromadzone przez nie wyniki ukazują moralność seksualną w coraz wyrazistszym i pełniejszym świetle, co ma niemałe znaczenie również dla etyki seksualnej. W tym zakresie postulat interdyscyplinarnej współpracy znajduje pełne zastosowanie. Do tego jednak, aby nie stał się on okazją do pomieszania pojęć i bezowocnych sporów naukowych, dojść musi jeszcze jeden warunek: poszczególne dyscypliny nie mogą wykraczać poza granice właściwych sobie założeń teoretycznych. Dyscypliny te bowiem różnią się między sobą nie tylko tym, że badają inne aspekty moralności seksualnej, ale czynią to także $z$ innego stanowiska $i \mathrm{w}$ inny sposób. Pod tym względem szczególnie ostra linia demarkacyjna przebiega między etyką seksualną a szczegółowymi naukami seksuologicznymi. Wyznacza ją trzeci, a zarazem ostatni przedmiot etyki seksualnej, tzw. ,,przedmiot formalnometodologiczny". 
Termin ,przedmiot formalnometodologiczny” etyki seksualnej oznacza ten jej wyłącznie właściwy kąt widzenia, jaki zajmuje ona względem przedmiotu formalnotreściowego, czyli ideałów, ocen i norm odnoszących się do seksualnych zachowań człowieka. Idzie o to, że etyka seksualna ma określić moralne podstawy i reguły postępowania człowieka w sferze życia seksualnego. Do jej zadań należy przeto ustalić moralny sens i przeznaczenie seksualnych zachowań człowieka, wniknąc w istotę właściwego im dobra i zła moralnego oraz rządzącego nim imperatywu moralnego, aby na podstawie uzyskanych tą drogą zasad ująć i sformułować odpowiednie oceny oraz nakazy i zakazy moralne. Inaczej mówiąc, zadaniem etyki seksualnej jest stwierdzić, co w zakresie życia seksualnego jest moralnie dobre, a co złe, co w tym względzie człowiek czynić powinien, a czego czynić mu nie wolno.

Otóż w tym właśnie punkcie zaznacza się istotna różnica między szczegółowymi dyseyplinami seksuologicznymi a etyką seksualną. Fizjologia człowieka, psychologia, socjologia czy etnologia moralności poruszają się wyłącznie w zjawiskowej sferze płciowej struktury czlowieka, jego moralnych przeświadczeń i faktycznych zachowań. Jak to już było wspomniane, w zakresie ich badań leży ustalenie, co „zachodzi”, co „się zdarza", jak ,jest" w tej dziedzinie, opisać to i wykryć występujące tu prawidłowości.

Natomiast etyka seksualna jest nauką filozoficzną i normatywna. Sięga przeto do ostatecznych racji seksualnych struktur i zachowań człowieka, orzeka, na czym polega właściwy im sens, dobro i imperatyw, jakie człowieka obowiązują oceny i normy postępowania. W przeciwieństwie do szczegółowych nauk seksuologicznych, które mają charakter opisowy, etyka seksualna należy do kategorii nauk normotwórczych, zbuỉowana przez nią konstrukcja peinni rolę miary i reguły, do której człowiek winien dostosować swoje zachowanie, jeżeli ma zrealizować właściwą sobie doskonałość moralną. Ta normotwórcza funkeja jest właściwa wyłącznie etyce seksualnej i żadna inna nauka szczegółowa nie potrafi jej zastąpić w wykonywaniu tego zadania.

Dodajmy, że o etyce seksualnej można powiedzieć coś więcej. Budując filozoficznie uprawomocniony system ocen i norm tworzy ona konstrukcję, która pełni rolę obowiązującego kryterium nie tylko bezpośrednio dla zachowań seksualnych czlowieka, ale także dla żywionych przezeń odnośnych intuicji moralnych, czyli wyznawanej przez poszczególne jednostki i całe grupy społeczne „,moralności seksualnych”. Jako elementy życiowej praktyki wymagają one metodycznej refleksji i sprawdzenia. Etyka seksualna konstruuje więc jakby ,drugą moralność", która będąc rezultatem filozoficznego myślenia przedstawia się równocześnie jako moralność „wyższego rzędu”. Na tej podstawie wy- 
stępuje względem potocznie funkcjonującej moralności seksualnej w charakterze sędziego i cenzora, wyrokującego, czy akceptowane społecznie intuicje moralne odnośnie do życia seksualnego odpowiadają wzorcom ustalonym na drodze myślenia filozoficznego przez etykę seksualną, czy też nie. Odpowiednio do tego, jak wypadnie przeprowadzony przez nią egzamin, utrwalone w świadomości ludzi i całych grup społesznych wartości, wzorce i normy zachowania seksualnego będą mogły być uznane za rzeczywistą, autentyczną moralność, bądź też za jej dewiację i wypaczenie.

Trojaki jest zatem przedmiot etyki seksualnej, gdyż badana przez nia kategoria zjawisk jawi się w trzech zasadniczych aspektach. Nie rozbija to jednak logicznej spoistości etyki seksualnej, gdyż aspekty te pozostaja we wzajemnej wewnętrznej zależności. Tworzą jakby trójstopniową piramidę, której dwa pierwsze stopnie są wspólne etyce seksualnej i innym naukom, a dopiero ostatni, mianowicie przedmiot formalnometodologiczny jest jej wyłącznie właściwy. On wyciska na etyce seksualnej znamienne piętno, dzięki któremu występuje ona w rzędzie nauk seksuologicznych jako nauka swoistego rodzaju, niesprowadzalna do żadne: z nauk szczegółowych, zrośnięta z filozofią moralności i filozofią w ogóle jako jej integralna część, uczestnicząca w jej blaskach, ale też i w cieniach. Specyficzna odrębność etyki seksualnej, zapewniając jej wyjątkowe miejsce wśród nauk seksuologicznych, tworzy równocześnie próg, na którym się potyka scjentystyczna i naturalistyczna negacja jej naukowego charakteru. Dodatkowym naświetleniem i pogłębieniem tego samego zagadnienia będą rozważania poświęcone źródłom poznania w etyce seksualnej.

\section{b) Zródła etyki seksualnej}

Stwierdzony przed chwilą fakt, że etyka seksualna stanowi - mocą swego przedmiotu formalnometodologicznego - integralną część etyki jako filozofii moralności, przesądza w pewnym stopniu sprawę jej źródeł. Zasadniczo rzecz biorąc muszą one być te same co w etyce ogólnej. W etyce zaś ogólnej mówi się o dwojakim źródle poznania: o doświadczeniu i zasadach rożumowych. Trudności występują dopiero wtedy, kiedy przystępuje się do dokładniejszego uściślenia tych terminów w odnie-sieniu do etyki seksualnej.

\section{DOŚWIADCZENIE}

O jakim doświadczeniu można mówić w etyce seksualnej? Pierwsze niejako rozumienie chciałoby tym terminem objąć ogół doznań związanych $\mathrm{z}$ aktualizacją seksualnych uzdolnień i dążeń człowieka. Wtedy 
jednak powstaje pytanie, co sądzić o osobach, które nie przeszły inicjacji seksualnej, bądź żyją w celibacie. Czy należy powiedzieć, że u tego rodzaju osób nie zachodzi w ogóle zjawisko doświadczenia seksualnego, do którego odwołuje się etyka seksualna? A jeżeli tego rodzaju doświadczenie u nich zachodzi, to czy tylko jako doświadezenie „pośrednie”, czerpane $\mathrm{z}$ drugiej ręki ${ }^{18}$, mianowicie $\mathrm{w}$ tych wypadkach, kiedy pracując $\mathrm{w}$ charakterze psychologa, psychiatry, a przede wszystkim spowiednika mają wgląd w cudze sumienia i uzyskują od nich wymagane informacje?

Jak się zdaje, umieszczenie problemu doświadczenia etyki seksualnej na płaszczyźnie doznań towarzyszących w jakikolwiek sposób seksualnej aktywności człowieka dotyka tylko pewnego, fragmentarycznego odcinka znacznie szerszej rzeczywistości. Chcąc tę rzeczywistość zakreślić w jej pełnych wymiarach należy dokonać pewnego rozróżnienia. W całokształcie danych koniecznych dla etyki seksualnej do wykonania właściwych jej zadań, zaznacza się fundamentalna różnica, która idzie po linii wskazanej uprzednio odrębności pomiędzy przedmiotem materialnym i formalnotreściowym etyki seksualnej. Odpowiednio do tego $\mathrm{w}$ kategorii doświadczenia jako źródła etyki seksualnej odróżnić należy dwojakie doświadczenie: jedno pozaetyczne, oraz drugie etyczne.

Zacznijmy od doświadezenia pozaetycznego. Skupia się ono wokół przedmiotu materialnego etyki seksualnej. W obrębie tego doświadczenia znajdują się wszystkie stwierdzenia dostarczone przez nauki szczegółowe (biologia, anatomia, fizjologia, psychologia) na temat anatomii i fizjologii płciowej struktury człowieka i jego aktywności seksualnej oraz psychologii przeżyć związanych z tą sferą jego życia, a także wiadomości potoczne na te same tematy. Odnośnie do ostatniej kategorii faktów wypada zaznaczyć, że dla ich zaistnienia nie jest konieczna ani inicjacja seksualna, ani uprawianie życia seksualnego. Wystarcza doświadczenie popędu seksualnego, który przez cały ciąg życia należy do wyposażenia biopsychicznego każdego normalnie rozwiniętego osobnika i umożliwia mu uzyskanie wiedzy, na czym polega życie seksualne. Mimo wą̧ystko punkt ciężkości doświadczenia pozaetyeznego opiera się na wynikach nauk seksuologicznych. Przemawia za tym przede wszystkim fakt, że w wyniku intensywnych badań doszło do znacznej rozbudowy faktografii seksuologicznej, przy czym proces ten wykazuje nadal tendencję zwyżkową. Wzrósł więc ogromnie zasób wiadomości, jakimi w dziedzinie seksuologii dysponuje wiedza współczesna. W wielu sprawach naiwne lub falszywe poglądy minionych wieków ustąpiły miejsca rzeczowo sprawdzonym informacjom, poznano wiele faktów uprzednio

18 K. kard. Wojtyła, Miłość i odpowiedzialność, Kraków 1962², 5-6. 
badawczej myśli ludzkiej zupełnie nieznanych, uzyskane dane ujęto w lepiej uporządkowane całości.

W nagromadzonym tą drogą zasobie wiadomości naukowych, jak też w danych poznania potocznego rzeczą etyka jest dobrać i uwzględnić w swoich rozważaniach te uściślenia i w takim zakresie, w jakim domaga się tego realizowane przez niego zadanie badawcze lub dydaktyczne. Szczególnie jeśli chodzi o przedstawienie stanu wiedzy w zakresie szcze-. gółowych nauk seksuologicznych, ze stanowiska naukowego etyk jest za to tylko odpowiedzialny, a nie za specjalistyczno-merytoryczną ich stronę. Do obowiązków etyka należy tylko rozpoznanie, czy dobrane przezeń źródła referują obiektywny i współczesny stan wiedzy na interesującym go odcinku.

Jak się zdaje, wystarczającą dla etyka dokumentację zawierają wydawane ostatnio różne ,seksuologie" ${ }^{19}$, a także monograficzne opracowania poszczególnych psychologów ${ }^{20}$, pedagogów ${ }^{21}$, czy moralistów ${ }^{22}$. Z uwagi na łatwość i dostępność tych źródeł oraz (choć niedoskonałą ${ }^{23}$ ) powszechną elementarną wiedzę o tym przedmiocie anatomiczna, fizjo-logiczna czy p.jychologiczna, krótko mówiąc zjawiskowa strona problematyki seksuologicznej zostanie w niniejszym studium zredukowana do koniecznego minimum. Za takim potraktowaniem doświadczenia pozaetycznego przemawia również fakt, że większe znaczenie dla etyki seksualnej mają dane drugiego typu doświadczenia, mianowicie doświadczenia etycznego. O tym zaś doświadezeniu mówi się $\mathrm{w}$ nauce względnie rzadko. Rzecz wymaga zatem objaśnienia.

Doświadczenie etyczne odnosi się do przedmiotu formalnotreściowego etyki seksualnej. Jak nam już wiadomo, przedmiotem tym jest „moralność seksualna", czyli te treści naszej świadomości, które wyrażają nasze własne intuicje, inaczej mówiąc przeświadczenia moralne, a więc oceny, normy i wzory osobowe, uznane przez nas za reguły naszego postępowania w sferze życia seksualnego. W tak określonej moralności sek . sualnej występuje niewątpliwie czynnik intelektualny: moralność ta obejmuje przecież odpowiedni zespół stanów naszego intelektu. Doświadczenie etyczne zachodzi więc wtedy, gdy sobie te stany uświadamiamy. W związku z tym doświadczenie etyczne polega na swoistej „,metaświadomości". Oznacza ono tę, tylko człowiekowi właściwą, zdolność uświa-

19 Por. Seksuologia, pod red. K. Giese, tłum. z 3 wyd. niem. H. Flatau, E. Jezierska, Z. Złotnicki, Warszawa 1959; Seksuologia społeczna, pod red. K. Imielińskiego, Warszawa 1974.

20 Z. L. Starowicz, Eros, natura, kultura, Warszawa 1974; Erotyka w aspekcie zdrowia psychicznego, pod red. M. Grzywak-Kaczyńskiej, Warszawa 1975;3; J. Strojnowski, Eros $i$ cz'owiek, Kraków 1976.

21 Kozakiewicz, U podstaw wychowania seksualnego, Warszawa 1969, 29-54.

22. S. Olejnik, Katolicka etyka seksualna, Warszawa 1966, 33-64.

23 Starowicz, dz. cyt., 10; Erotyka w aspekcie zdrowia psychicznego, 9. 
damiania sobie własnych stanów świadomościowych o treści moralnej. Człowiek przy pomocy refleksji intelektu zwraca się ku żywionym przez siebie przeświadczeniem moralnym odnośnie do życia seksualnego, a poznając na tej drodze swoje własne idee o ocenach i normach ważnych dla niego w tej dziedzinie życia uzyskuje w ten sposób odpowiedni zespól danych, czyli „faktów etycznych”. Na nich się wspiera i do nich się odwołuje etyka seksualna.

Podane objaśnienie uwypukliło wewnętrzną i indywidualną stronę doświadczenia etycznego. Tymczasem ma ono także swój wymiar zewnętrzny i społeczny. W rozważaniach filozoficzno-etycznych odgrywa on znaczną rolę, ponieważ umożliwia przekształcenia doświadczenia indywidualnego $\mathrm{w}$ doświadczenie powszechne, czyli $\mathrm{w}$ pewnym przybliżeniu w doświadezenie ogólnoludzkie.

Rodzi się jednak pytanie, w jaki sposób moralne intuicje i przeświadczenia poszczególnych osób mogą stać się przedmiotem doświadczenia zewnętrznego w skali społecznej. Z pomocą przychodzą tu nam wszystkie środki, które służą człowiekowi do uzewnętrzniania własnych stanów świadomościowych i udostępnieniu ich dzięki temu poznaniu innych. Konkretnie mówiąc, chodzi o żywe słowo i pismo. Ma to zastosowanie również w etyce seksualnej, kiedy przy ich pomocy uzewnętrzniamy żywione przez nas intuicje moralne. $Z$ tych samych zresztą źródeł informacji korzystają psychologowie, w większym jeszcze stopniu socjologowie i etnologowie, badając świadomość moralną większych i mniejszych grup społecznych. Wyniki ich prac nie są obojętne dla etyki seksualnej. Poszerzają one ogromnie zasięg doświadczenia moralnego i to w dwojakim kierunku. Socjologia rejestruje aktualny stan moralności seksualnej w skali społecznej i pozwala stwierdzić przynajmniej elementarne prawidłowości zachodzące na tym odcinku jej naukowego badania. Historia kultury bada pojęcia moralne wielkich cywilizacji ludzkości. Etnologia natomiast sięga $\mathrm{w}$ przeszłość i badając tzw. ludy pierwotne gromadzi materiał, na podstawie którego można sobie urobić przybliżony obraz tej moralności w jej najstarszych, dziś jeszcze naszemu poznaniu dostępnych fazach rozwojowych. Co więcej świadomość moralna tych epok opiera się wyłącznie na społecznym tradycyjnym przekazie, występuje zatem w stanie „czystym”, ,nieskażonym”, czyli nie zmodyfikowanym narzutami refleksji filozoficznej lub teologicznej, ani też żadnej historycznie uwarunkowanej ideologii. Jest zatem rzeczą oczywistą, że osiągnięcia wymienionych nauk szczegółowych, a zwłaszcza etnologii, mają dla etyki seksualnej decydujące znaczenie, gdyż odtwarzają moralną świadomość w wielkim, ogólnoludzkim wymiarze. Kreślą przeto tło bardzo szerokie i wszechstronne dla rozważań filozoficzno-etycznych. W granicach ludzkich możliwości jest to niewątpliwie najbardziej mia- 
rodajne źródło poznania. Uwaga powyższa uzasadnia w pełni postulat, ażebry $w$ integralnie pojmowanej teorii etyki seksualnej wyniki etnologii (o ile się $\mathrm{w}$ ogóle o nich mówi) były uwzględniane w mierze wymaganej ich ciężarem gatunkowym, nie zaś w formie zdawkowych, mało mówiących: ogólników, czy jednostronnych, a przeto i nieadekwatnych sformułowań ${ }^{24}$.

Ogólnie więc powiedzieć można, że na całość danych doświadczalnych etyki seksualnej składają się stwierdzenia doświadczenia pozaeltycznego i etycznego. Pierwsze $z$ nich - doświadczenie pozaetyczne - obejmuje wyniki badań takich nauk, jak biologia, anatomia, fizjologia i psychologia. W niniejszym studium zakłada się ich znajomość na podstawie współczesnych opracowań seksuologicznych. Doświadczenie etyczne zawiera osiągnięcia przede wszystkim socjologii, historii kultury oraz etnologii. Globalnie ujęte mogą być nazwane „etologią” moralności seksualnej, jeżeli wolno posłużyć się w tym kontekście rzadko dziś w etyce występującym terminem Świętochowskiego.

\section{ZASADY ROZUMOWE}

Jeżeli doświadczenie dostarcza etyce seksualnej danych odnośnie do jej przedmiotu materialnego i formalnotreściowego, zasady rozumowe stanowia narzędzia poznawcze, przy pomocy których może ona opracować właściwy sobie przedmiot formalnometodologiczny. Jak to już kilkakrotnie było podkreślone, zadaniem etyki seksualnej jest zbudowaé konstruksję zasad i norm moralnych porządkujących seksualne zachowania człowieka i korygujących żywione przezeń tradycyjne intuicje i przekonania. Tego zadania - znowu przypominam rzeczy już powiedziane - nie potrafi wykonać żadna inna nauka seksuologiczna. Nawet etyka seksualna nie może mu podołać przy pomocy samego tylko doświadczenia, nie tylko pozaetycznego, ale nawet etycznego. Możliwe jest to tylko przy pomocy i na gruncie odpowiednich zasad rozumowych. One zatem stanowią niezbędne i niezastąpione narzędzie poznawcze etyki seksualnej, dzięki któremu może ona wykorzystać dla swych celów dane uzyskane na drodze doświadczenia. Stawiając zatem zagadnienie zasad rozumowych docieramy do podstawowego źródła wszelkich źródeł etyki seksualnej, a tym samym stajemy na gruncie na wskroś filozoficznym i etyczno-normatywnym.

Termin ,zasady rozumowe" ma w etyce chrześcijańskiej określone znaczenie ${ }^{25}$. Na ogół przez zasady rozumowe rozumie się pewien zbiór

24 Zob. M. Kozakiewicz, Moralne aspekty wychowania seksualnego, w: Seksuologia społeczna, 244; Fr. Böckle, Ethos der Liebe, w: Geschlechtliche Beziehungen vor der Ehe, Mainz $1967^{2}, 21$.

25 Por. T. Slipko, Zarys etyki ogólnej, 19, 22. 
ogólnych zasad, które przyjmuje się jako zdania prawdziwe i uzasadnione, aby przy ich pomocy uzasadniać odpowiednie twierdzenia normatywno-etyczne. W odniesieniu do etyki seksualnej definicja ta wymaga tylko krótkiego dopowiedzenia. Przez „twierdzenia normatywno-etyczne” rozumieć należy wartości, oceny i normy ważne w zakresie seksualnego życia ludzkiego. Od doświadczenia etycznego różnią się one tym, że nie występują w charakterze moralnych przeświadczeń jakiegoś podmiotu (indywidualnego lub zbiorowego) i nie są za takie uważane. W zasadach rozumowych istotną bowiem jest ich ogólna treść normatywna wzięta sama w sobie, niezależnie od takich czy innych podmiotów. Jeżeli ta treść ma za sobą wystarczające uzasadnienie, choćby wewnętrznoanalityczne, jak to ma miejsce w najogólniejszych zasadach myślenia i działania, i na podstawie tego uzasadnienia przedstawia się ludzkiemu intelektowi jako prawdziwa, wówczas wyrażona w formie sądu i odpowiedniego zdania może być zaliczona do kategorii zasad rozumowych. W tym charakterze służy do budowania filozoficznego systemu etyki seksualnej. Innymi słowy dwie cechy decydują o przynależności danego zdania ogólnego do zasad rozumowych: prawdziwość i stosowalność w rozważaniach filozoficzno-etycznych.

To czysto formalne określenie musi być dopełnione odpowiedzią na pytanie, skąd etyka seksualna czerpie właściwe sobie zasady rozumowe i które z nich mają dla niej szczególnie doniosłe znaczenie. Sprawa nie jest prosta, ponadto zakłada pewne ustalenia z etyki ogólnej ${ }^{26}$. Za punkt wyjścia posłuży stwierdzenie, że etyka seksualna jako integralna część szczegółowej etyki normatywnej kształtuje się zawsze w ścisłej zależności logicznej od określonego systemu filozoficznego i z niego czerpie najważniejsze elementy bazy metodologicznej, na której opiera swoje normatywne sformułowania. Przemawia za tym zarówno analiza omówionych stanowisk reprezentowanych aktualnie na gruncie etyki seksualnej, jak i wewnętrzne racje logiczne. Poglądy etyki marksistowskiej, Kotarbińskiego czy Witwickiego wypływają w tym samym stopniu z założeń materialistycznych lub naturalistycznych, w jakim poglądy Hildebranda czy kard. Wojtyły wypływają ze źródel teistycznych i spirytualistycznych. I tak być musi, gdyż niepodobna formułować ocen i norm ważnych dla seksualnego zachowania się ludzi, nie kierując się odpowiednią wizją samego człowieka, jego struktury i stanowiska we wszechświecie. Wynika stąd niepodważalna konsekwencja, że problem zasad rozumowych jako źródła etyki seksualnej sprowadza się do deklaracji, jaka filozofia, szczególnie zaś jaka antropologia filozoficzna zostanie obrana za podstawę metodologiczną rozważań normatywno-etycznych.

26 Por. T. Slipko, Zarys etyki ogólnej, 29-30, 35-43. 
Najogólniejsza ich orientacja nie nastręcza tutaj trudności. Jest bowiem rzeczą oczywistą, że zasadnicze ukierunkowanie zamierzonej etyki seksualnej pójdzie po linii wyznaczonej przez fundamentalne tezy filozofiii chrześcijańskiej. Do takich zaś należy przede wszystkim teza o transcendentnym zakorzenieniu człowieka. W świetle tej tezy człowiek jawi się jako byt przygodny i pochodny od Bytu absolutnego, którym jest osobowo pojmowany Bóg, czyli Istota nieskończona, a zarazem samoistny Intelekt i niezgłębiona Miłość. Z tego Bytu jako pierwszego źródła czerpie człowiek właściwą mu wielkość i godność, dzięki której zajmuje w porównaniu z resztą świata odrębne i jemu tylko właściwe i należne miejsce. W tym punkcie chrześcijańska etyka seksualna odcina się wyraźnie od stanowisk materialistycznych. Jej światopoglądowa postawa jest postawą teistyczną ${ }^{27}$.

Pluralistyczne tendencje myśli filozoficznej, które nie ominęły również filozofii chrześcijańskiej, sprawiły jednak, że w chwili obecnej założenia teistyczne stanowią zbyt słaby czynnik, ażeby przedstawicieli filozofii chrześcijańskiej związać w jedną szkołę etyczną, zwłaszcza jeżeli chodzi o jej stanowisko w etyce seksualnej. Dyskusje, jakie się toczą na naszych oczach i których mały fragment został zreferowany w poglądach Antoine'a i Davida dowodzą, że mimo wspólnej im inspiracji teistycznej doszło do znacznego zróżnicowania poglądów w centralnych nawet zagadnieniach antropologii chrześcijańskiej. W związku z tym zostały postawione pod znakiem zapytania te pojęcia i zasady, w których etyka seksualna znajduje swoje główne filary i nośniki całości.

Uzyskane w tym względzie materiały pozwalają ustalić trzy takie idee, które stanowią swego rodzaju punctum stantis vel cadentis etyki seksualnej, gdyż dokonane w nich rozstrzygnięcia teoretyczne decyduja o doktrynalnym profilu zbudowanej na nich teorii etycznej. Chodzi po prostu o to, jak rozumieć należy naturę ludzką, jakie czynniki uznać za decydujące dla moralnej specyfikacji aktu ludzkiego oraz jaki charakter i jaką moc obowiązującą przyznać normom składającym się na etykę seksualną. Są to jednak zagadnienia nazbyt skomplikowane, aby można było je rozwiązać za pomoca prostych konstatacji i w ten sposób ustalić fundamentalne zasady rozumowe, na których oprzemy się w przyszłości.

Konieczną jest rzeczą zarysować nieco szerzej ich kontekst filozoficzny, aby dokonany wybór wypadł bardziej przekonująco. Z tego samego względu uwagi i refleksje nad tą problematyką będą stanowić osobną część tego rozdziału. Natomiast w zakońezeniu tego wywodu wypada poświęcić parę słów zagadnieniu metody etyki seksualnej, gdyż należy ono również do integralnych składników metaetycznych rozważań nad etyką seksualną.

${ }^{27}$ Por. Z. Kozubski, Podstawy etyki ptciowej, Warszawa $1955^{3}, 11-12$. 


\section{c) Metoda etyki seksualnej}

Ustalenia, do jakich doprowadziły rozważania nad przedmiotem i źródłami etyki seksualnej, przesądzają w pewnym stopniu problem metody etyki seksualnej. Jeżeli bowiem przedmiot materialny i formalnotreściowy etyki seksualnej zawiera w sobie pewne aspekty dostępne doświadczeniu pozaetycznemu i etycznemu, przedmiot zaś formalnometodologiczny jest możliwy do poznania tylko w świetle zasad rozumowych, w takim razie metoda etyki seksualnej musi polegać na odpowiednim zintegrowaniu danych zaczerpniętych $\mathrm{z}$ obu tych źródeł poznania. Do rozstrzygnięcia pozostaje jedynie kwestia, na jakich zasadach ma się to zintegrowanie dokonać i jak poszczególne elementy winny być wykorzystane w zamierzonym procesie badawczym.

Kierując się przesłankami wziętymi z ogólnej koncepcji metody etyki ${ }^{28}$ należy przyjąć, że również na terenie etyki seksualnej ma zastosowanie metoda, której punkt wyjścia znajduje się w danych doświadczalnych. Pozwala to dojrzeć podstawowe antynomie charakteryzujące świat pojęć i zasad moralności seksualnych, następnie zaś sformułować na tej podstawie najważniejsze zagadnienia, które stają do rozwiązania przed myślą filozoficzną. Jednakowoż główny punkt ciężkości metody etyki seksualnej spoczywa na zasadach rozumowych. Ich zestaw odpowiednio dobrany pozwala zarówno dokonać wymaganych analiz filozoficznych i sprecyzować pojęcia charakterystyczne dla etyki seksualnej, jak też skonstruować niezbędną motywację rozumową na rzecz stawianych twierdzeń. Oczywiście budowa uzasadnień nie może się dokonywać według jednego schematu rozumowania. Musi się ona dostosowywać do treści uzasadnianych twierdzeń i przybierać taką postać, jak się tego domaga stopień ich ogólności i miejsca w logicznej strukturze konstruowanej teorii. Może to więc być intelektualna analiza pojęć, wnioskowanie bezpośrednie, ale też pośrednie, dedukcyjne ${ }^{29}$.

Ogólnie natomiast podkreślić należy, że wszystkie te środki myślenia wyjaśniającego i dowodzącego mieszczą się w obrębie ludzkiej ratio i praw rządzącej nią logiki. Choć więc nie jest to typ myślenia empirycznego, to jednak różni się też zasadniczo od myślenia intuicyjnego typu bergsonowskiego czy fenomenologicznego. Myśleniu empirycznemu ma do zarzucenia, $\dot{z}$ e nie prowadzi ono, jak to już było powiedziane, do żadnych uprawnionych wniosków normatywnych. Nie uznaje również intuicyjnej drogi dochodzenia do zasad moralnych, ponieważ $w$ tej właśnie metodzie dopatruje się zalążków irracjonalizmu i subiektywizmu. Szczególnie w zakresie moralności seksualnej może to doprowadzić do nie-

28 Por. Slipko, Zarys etyki ogólnej, 27-30, 22-27.

29 Por. Z. Kozubski, Podstawy etyki ptciowej, 10. 
bezpiecznych konsekwencji w postaci aprobaty moralności dowolnie określanej przez każdą z osobna wziętą jednostkę.

Chrześcijańska etyka seksualna obiera drogę pośrednią: doświadczalno-racjonalną. Wychodzi $\mathrm{z}$ doświadczenia, ale podstawowe narzędzia poznawcze w dochodzeniu do prawdy moralnej upatruje w zdolnościach rozumu docierania ,do prawd w nich (danych doświadczenia - TS) ukrytych, względnie celów zamierzonych przez naturę" ${ }^{30}$. Wznosi sif tym samym na poziom myślenia, które odkrywając zasadnicze elementy porządku normatywnego równocześnie pozostaje podatne na kryteria dostępnej etyce filozoficznej sprawdzalności i intersubiektywności. W takim ustawieniu stosowanej przez siebie metody chrześcijańska etyka seksualna uzyskuje możność przezwyciężenia zarówno niewystarczalności metody czysto empirycznej, jak i przerostów skrajnego intuicjonizmu. Nie pozostaje też bezbronna wobec zarzutów neopozytywizmu i emotywizmu. Buduje system w filozoficznym sensie naukowy i logicznie spójny.

\section{ETNOLOGIA A ETYKA SEKSUALNA}

Rozważania nad przedmiotem i źródłami etyki seksualnej ukazały konieczność szerszego, niż się to zazwyczaj dzieje, uwzględnienia danych etnologicznych przy szkicowaniu doświadezenia moralnego w zakresie moralności seksualnej. A tymczasem zaraz na wstępie rodzi się pewna trudność, która godzi w same podstawy wysuniętego przed chwilą twierdzenia o wielkiej roli badań etnologicznych dla etyki seksualnej. R. Bastide swoją rozprawę pt. Rzeczywistość ptci u ludów pierwotnych rozpoczyna od słów: „Nie ma już ludów pierwotnych. Nawet ludy... pozostające jeszcze na stopniu zbieractwa nie żyją już tak, jak żyli ich przodkowie"31. Uwaga z całą pewnością słuszna, gdyż rozwój ludzkości od samego początku dokonuje się poprzez kontakty międzygrupowe, które modyfikują strukturę i świadomość społeczną. Proces ten posunął się tak daleko, że nie rozporządzamy dziś żadnymi możliwościami dotarcia ảo jego stanu wyjściowego. Prawdą też jest, że liczba ludów pierwotnych powoli, ale coraz bardziej maleje.

Nie o to jednak chodzi w naszym wypadku. Ujmując rzecz w wielkim skrócie należy stwierdzić, co następuje: $1^{\circ}$ Nie wszystkie ludy pierwotne były w jednakowym stopniu wystawione na wielorakie wpływy innych kręgów kulturowych. Do dziś jeszcze znajdują się między nimi takie, które żyją w stanie wielkiej izolacji. $2^{\circ}$ Niewątpliwe oddziaływania kulturowe jednych ludów pierwotnych na inne zachodziły mimo

30 Kozubski, Podstawy etyki piciowej, 10.

31 R. Bastide, Rzeczywistość ptci u ludów pierwotnych, w: Natura, kultura, płeć, 55. 
wszystko w ramach wspólnej im wszystkim tradycyjnej kultury społecznej i były jej wyłącznym wytworem. Należą przeto do przedrefleksyjnej i przednaukowej fazy spolecznego rozwoju ludzkości. Nacisk cywilizacji europejskiej jest późniejszej daty i na ogół nie był tak powszechny, ani tak głęboki, aby naruszył tradycyjne kultury pierwotne u samych ich podstaw i pozbawił je ich własnego oblicza. $3^{\circ}$ Spośród różnych kategorii składających się na całość kultury ludów pierwotnych kultura duchowa, w jej zaś obrębie wierzenia religijne i kodeksy moralności, obwarowane częstokroć plemiennym tabu, należały do elementów najbardziej odpornych na wpływy zewnętrzne. Jeżeli zaś w pewnych ośrodkach, np. w rejonach misyjnych, ustępowały miejsca religii i obyczajowości chrześcijańskiej, działo się to powoli i z niemałymi oporami. Zachodzące procesy, zwłaszcza pierwotny, przedchrześcijański stan świadomości danych ludów, mają niekiedy swoją dokumentację w postaci relacji misjonarzy lub uczonych i dzięki temu mogą być zaliczone do źródeł etnologicznych. Obawy Bastida nie są więc aż tak uzasadnione, aby mogły podważyć znaczenie zebranych $z$ tego terenu danych dla zrekonstruowania moralnej świadomości ludów pierwotnych w zakresie moralności seksualnej w skali, o ile możliwe, najszerszej, nawet ogólnoludzkiej. Etnologia od dawna interesowała się życiem seksualnym ludów pierwotnych gromadząc dane dotyczące zarówno ich zachowań seksualnych, jak też obyczajów i norm obowiązujących $w$ tej dziedzinie życia ${ }^{32}$. Wielkość nagromadzonego materiału pozwoliła $z$ biegiem czasu na dokonanie odpowiednich klasyfikacji oraz zbudowanie uogólniających je i wyjaśniających teorii. Owszem, w pewnych wypadkach konstruowanie teorii wyprzedziło znacznie proces gromadzenia faktów. Dowodem na to są ewolucjonistyczne teorie małżeństwa i rodziny z końca XIX w. Jeżeli chodzi o potrzeby etyki seksualnej, teorie etnologiczne mają o wiele mniejsze znaczenie, aniżeli fakty, i to fakty nie tyczące zachowań seksualnych ludów pierwotnych, ale kierujących ich postępowaniem pojęć i zasad moralnych. Pod tym kątem widzenia zostaną ujęte interesujące nas dane etnologiczne.

Pierwszym faktem, który w świetle dzisiejszej etnologii nie ulega wątpliwości, jest powszechność istnienia w moralnej świadomości ludów pierwotnych wyraźnie rysującego się zespołu różnorakich zasad i norm ${ }^{33}$ Twierdzenie XIX-wiecznych ewolucjonistów (L. Morgan, H. Spencer),

32 Por. E. Westermarck, The History of Human Marriage, t. 3. New York 19225; W. Schmidt, Lięe, Ehe, Familie, Innsbruck 1931; J. Müller, Das sexuelle Leben der Völker, Paderborn 1935; B. Malinowski, Życie seksualne dzikich w pótnocno zachodniej Melanezji, Warszawa 1938; R. Mohr, Die christliche Ethik im Lichte der Ethnologie, München 1954; R. Bastide, Rzeczywistość płci u ludów pierwotnych, w: Natura, kultura, płeć, 55-73.

${ }_{33}$ Mohr, Die christliche Ethik im Lichte der Ethnologie, 82. 
że w dziejach ludzkości istniał stan, w którym życie seksualne ludzi nie podlegało żadnej reglamentacji, pozbawiony jest wszelkich podsitaw empiryeznych. Okazuje się arbitralnym wnioskiem, wysuwanym z idei ewolucji, ale $w$ jaskrawej niezgodzie $z$ rzeczywistością. Wręcz przeciwnie współczesnych etnologów uderza ilość i siła zakazów i nakazów moralnych, które ujmują życie seksualne wielu społeczeństw pierwotnych w ściśle określone ramy sięgające aż do najbardziej intymnych jego przejawów ${ }^{34}$. Moralność seksualna jest zatem zjawiskiem ogólnoludzkim, towarzyszącym człowiekowi od samego zarania jego historii aż po dzień dzisiejszy.

Dane etnologiczne świadczą także wystarczająco, że moralność seksualna społeczeństw pierwotnych pozostaje w bardzo ścisłym związku z całym kontekstem kulturowym, w obrębie którego żyją te społeczeństwa ${ }^{35}$. Ponieważ kontekst ten jest bardzo różnoraki, przeto kulturowe powiązania tkwiącej w nim moralności seksualnej kształtują się na rozmaitych płaszczyznach. Niektóre z nich dotykają tylko peryferycznych aspektów moralności, np. różne regionalne zwyczaje, które określają usankcjonowane społecznie formy rytualnych inicjacji młodzieży w tajniki życia seksualnego, odpowiednich form życia towarzyskiego, ceremoniału zaślubin, sankcji, jakie poszczególne społeczeństwa nakładają na osoby winne naruszenia obowiązujących w ich obrębie norm moralnych i tym podobne zjawiska. Inne wszakże rzutują bardzo głęboko na moralny sens płciowości i życia seksualnego. Dlatego nie mogą być pominięte. Wśród etnologów zachodzi różnica zdań przy wyjaśnianiu podstawowych czynników kulturowych kształtujących treść moralności seksualnej u ludów pierwotnych. Np. szkoła historyczna w etnologii wiązała odrębnośé różnych typów moralności seksualnej u ludów pierwotnych z ich patriarchalną i matriarchalną strukturą społeczną. R. Mohr - zresztą w nawiązaniu do innych współczesnych etnologów - jest innego zdania, jak się zdaje lepiej uzasadnionego ${ }^{36}$. Nasze przedstawienie rzeczy pójdzie po linii jego wywodów.

Autor ten za bardzo ważne dla kulturowego uwarunkowania moralności seksualnej ludów pierwotnych uważa jej powiązania z ideologiczną perspektywą, jaka charakteryzuje świat pojęć tych ludów. Mianowicie da się stwierdzić dwojaka postawa w przyjmowanym przez te społeczeństwa obrazie świata i człowieka. Jedną z nich znamionuje religijne pojmowanie świata. Swiat w myśl tej ideologii jest tworem ponadświatowych, często osobowo pojmowanych sił, które ustanawiają panujący

34 Bastide, Rzeczywistość plci u ludów pierwotnych, 65. Autor ma przed oczyma głównie ludy afrykańskie, ale podobny stan rzeczy występuje również u ludów pierwotnych na innych kontynentach.

35 Malinowski, Zycie seksualne dzikich, s. XLI-XLIII.

36 Mohr, Die christliche Ethik im Lichte der Ethnologie, 5-20. 
w nim porządek rzeczy. Częścią tego ogólnego ładu jest porządek moral ny, który swoim zasięgiem ogarnia również życie seksualne ludzi i wyznacza obowiązujące ich normy postępowania, ,gdyż — jak wierzą -mężczyzna i kobieta są dla siebie nawzajem przeznaczeni, aby wieść życie w małżeńskiej wspólnocie i rodzinie" ${ }^{37}$. Zakorzenienie moralności seksualnej w ponadświatowym, boskim ładzie powoduje, że podporządkowanie się jej nakazom uchodzi w świadomości moralnej tych społeczeństw za rzecz oczywistą i nie budzącą sprzeciwu ${ }^{38}$.

Światopogląd innych ludów przeniknięty jest pierwiastkami magii. W świecie widzi on wielką rzeczywistość natury, wyposażoną w potężne prasiły, które swe przedłużenie znajdują w człowieku i umożiiwiają mu tworzenie porządku społecznego. Moralność seksualna jest w tym kontekście funkcją wewnątrzświatowego sysitemu sił, którego najgłębszy sens leży w połączeniu pierwiaistka męskiego i żeńskiego jako źródła ży-cia we wszechświecie. Jak stwierdza Mohr, w tym światopoglądziء ,płciowość jest wielką magią, ogarniającą, wypełniającą i utrzymująca świat" 39. Dlatego leży w mocy człowieka wzmocnić ,magiczne siły od strony ich domniemanych źródeł za pomocą totemistycznego systemu klanowego i sztucznego spotęgowania seksualnych napięć za pomoca sztucznego przepołowienia szczepu na dwie grupy w powiązaniu $z$ nienaturalnym rozdziałem płci w codziennym życiu" 40.

Ilustracją zarysowanych różnić w światopoglądowych postawach ludów pierwotnych jest stan mentalności dwu szczepów pigmejskich, Ituri z Afryki środkowej i Semangów z Półwyspu Malakka, aczkolwiek przytoczyć by można jeszoze caly szereg innych ludów z różnych rejonów geograficznych ${ }^{41}$. Mimo to wyraźne rozgraniczenie dwu światopoglądów i funkcjonujących $w$ ich ramach moralności seksualnych tylko w pewnym stopniu odpowiada obiektywnemu stanowi rzeczy, w którym wspomniany ostry dualizm postaw światopoglądowych ulega pewnemu zatarciu na skutek mieszania się elementów magicznych z religijnymi w obrębie duchowego świata tyıh samych szczepów. Nie podważa to jednak zasadności wspomnianego rozrćżnienia choćby $w$ imię tej racji, $\dot{z}$ e w światopoglądowych pojęciazh ludów pierwotnych zaznaczają się takie dwa fundamentalne nurty i że jeden z nich zajmuje czasem wyłączną, kiedy indziej zaśs dominujązą pozycję w duchowej strukturze tych idẹlogii. W zależności zaś od tego, na którym z tych nurtów opiera się moralność seksualna ludów pierwotnych, jej sens moralny ulega modyfikacji: nabiera charakteru transcendentnego lub immanentnego. Dualizm

\footnotetext{
37 Dz. cyt., 87.

38 Dz. cyt., $10,87$.

39 Dz. cyt., 131.

40 Dz. cyt., 10.

41 Dz. cyt., 11-20.
} 
światopoglądów pierwotnych przechodzi w świadomości ludów pierwotnych $\mathrm{w}$ dualizm ostatecznych podstaw i genezy moralności seksualnych.

W związku z włączeniem moralności seksualnej w określoną strukturę światopoglądową pozostaje ogólna ocena płciowości i życia seksualnego. U ludów, dla których porządek moralny jest tworem sił pozaświatowych, ta ocena ma charakter etyczny, ale występuje w postaci przeświadczenia o istnieniu $\mathrm{w}$ płciowości, tym bardziej w samym akcie seksualnym jakiegoś moralnego nieporządku. Nieporządek ten wywodzi się z jakiegoś pierwotnego grzechu, który polegał na niezgodnym z wolą Bożą stosunku cielesnym, ponieważ został dokonany poza normalnym pożyciem małżeńskim. Wskutek tego Bóg oddalił się wtedy od ludzi. Idea ta bardzo wyraziście występuje szczególnie we wierzeniach szczepu Bubi (Fernando Poo) ${ }^{42}$. Są jednak ludy, które nawet $w$ małżeńskim pożyciu seksualnym widzą jakieś moralne zło $^{43}$. Takie pojmowanie moralności seksualnej charakteryzuje świadomość moralną wielu ludów afrykańskich (Pangwe, Kamerun, Hona-Adamana, Nandi - Afryka wisch.), Oceanii i mórz południowych (Archipelag Bismarcka), Syberii (Zyrianie - płn.-zachodnia Syberia) i innych ${ }^{44}$. Przejawem tego jest fakt, że w języku jednych pożycie seksualne określa się wyrazem „brud”, lub „coś co zakaża”, u innych płciowość oznacza zło. Z tym przeświadczeniem łączy się idea zadośćuczynienia i pokuty, która wyraża się np. w symbolicznym rytuale zabijania człowieka w toku inicjacji przedmałżeńskich ${ }^{45}$. Dopiero po spełnieniu takiej ofiary członkowie tych szczepów mogą prowadzić życie małżeńskie bez obaw, że ściągnie to na nich śmierć jako karę bóstwa. Swiadomość uzyskanego oczyszczenia pozwala im odnosić się do płciowości z pewnym szacunkiem i w jej używaniu widzieć spełnienie zamiarów Stwórcy.

W magiczno-immanentnym światopoglądzie ludów pierwotnych ocena płciowości i za'chowań seksualnych człowieka ulega zasadniczej zmianie. Pojmuje się je nie tylko jako elementy kosmicznego układu sił, ale nawet, jak to było podkreślone, $\mathrm{w}$ pewnym stopniu uitożsamia się je $\mathrm{z}$ tym systemem. Skoro więc w tym światopoglądzie płciowość stanowi przejaw wszechświatowego pierwiastka witalnej żywotności, nic dziwnego, że ani sama płciowość, ani obcowanie płciowe nie jest czymś ,złym”, „moralnie nagannym”, „nie podlega też karze, ani obecnie ani później” ${ }^{46}$.

Uitożsamienie płciowości z witalną żywiołowością natury staje się w omawianym kręgu kulturowym źródłem szeroko na kuli ziemskiej rozpowszechnionego kultu płodności symbolizowanej za pomocą orga-

42 Dz. cyt. $111-112$.

43 Dz. cyt., 102, 130.

44 Dz. cyt., $102-104$.

45 Dz. cyt., 130.

46 Dz. cyt., 131.

Analecta -8 
nów płciowych męskich i kobiecych. Zjawisko to występuje zresztą nie tylko u ludów pierwotnych, ale też w rozwiniętych cywilizacjach antycznego świata śródziemnomorskiego, Indii, Chin i Japonii. Ciekawy szczegół notują etnologowie na wyspie Flores ${ }^{47}$. Czczone przez tubylców bóstwo nosi imię Lera-Wulan, czyli Słońco-Księżyc i pojmowane jest jako Matko-Mą̇. Ale ten sam wyraz oznacza także męskie narządy płciowe. Żeńskim odpowiednikiem tego bóstwa jest Ziemia nazywana Ojco-Kobieta, symbolizowana znowu za pomocą kobiecych organów płciowych. Natura bóstwa polega tedy na przenikaniu się pierwiastka męskiego i kobiecego, to zaś przenikanie określa pierwotny stan rzeczy, który człowiek pierwatny odkrywa i czci w płciowym zróżnicowaniu mężczyzny i kobiety ${ }^{48}$.

Idea magicznego sprzężenia męsko-żeńskich pierwiastków życia przejawia się również $\mathrm{w}$ ideowej treści inicjacji poprzedzających małżeńlstwo oraz treści samego małżeństwa. Inicjacje przedmałżeńskie nie są - jak $\mathrm{w}$ transcendentnej orientacji światopoglądowej — przygotowaniem do małżeństwa, ale rytem, którego zadaniem jest wcielić jednostkę we wspólnotę szczepową. Ale rzeczywistość tego szczepu jest również zbudowana na magicznej zasadzie życiodajnego związku pierwiastka męskiego i żeńskiego $\mathrm{w}$ społecznym organizmie szczepu ${ }^{49}$. Szczep jest zatem pierwszym podmiotem płciowości i płodności. W związku z tym małżeństwo nie jest na pierwszym miejseu wspólnotą osobową, ale uczestniczeniem w życiotwórczej mocy szczepu dzięki życiowemu zespoleniu pierwiastka męskiego i żeńskiego. Za pośredniatwem zaś szczepu małżeństwo sięga aż do pierwiszych kosmicznych źródeł życia i energii. Czczone przez Zulusów (płld. Afryka) bóstwo o magicznym męsko-żeńskim ukształtowaniu zwane Ulunkulu nie bytuje poza granicami widzialnego świata. Według plemiennego mitu w akcie stworzenia wniknęło ono w pierwszą wspólnotę Zulusów jako jego wewnętrzna dynamiczna zasada, z której bierze początek i którym przeniknięte jest życie i działalność całego szczepu ${ }^{50}$. Jego więc struktura społeczna musi odpowiadać naturze kiształtujących go sił. Dlatego społeczeństwa tego kręgu podzielone są na dwie grupy, męską i żeńską, odgrodzone od siebie licznymi barierami społecznego obyczaju. Dopiero na gruncie płciowości dokonuje się ich zbliżenie i komunikacja. Mimo wszystko, aby zbliżenie to nie stało się jakimś naruszeniem ładu, musi się dokonywać w granicach określonych przez społeczeństwo ${ }^{51}$.

47 Dz. cyt., 131-132.

48 Dz. cyt., 132.

49 Dz. cyt., 132.

50 Dz. cyt., 133-134.

${ }_{51}$ Dz. cyt., 125-126; Bastide, Rzeczywistość płci u ludów pierwotnych, 71-73. 
Utożsamienie płciowości z kosmicznym układem sił w magiøznym obrazie świata prowadzi w końcu do oderwania płciowości od jej naturalnego przeznaczenia, czego najbardziej jaskrawym przykładem jest usankcjonowanie homoseksualizmu u niektórych plemion tego kręgu kulturowego jako jednego z elementów struktury społecznej (Bafia w Kamerunie, Marind-Anim na Nowej Gwinei) ${ }^{52}$. Większe znaczenie ma tu wszakże fakt, że w świadomości magiıznie myślącego człowieka pierwotnego twórcza moe płciowości przemienia się w końcu w narzędzie, przy pomozy którego usiłuje on wpływać na przyrodę i ludzi, aby kierować biegiem spraw zgodnie ze swą wola i interesami. Zjawisko to wy.stępuje w dziedzinie życia gospodarczego, polityəznego, nawet religijnego. Przybiera ono postać najróżnorodniejszych praktyk magicznych, stanowiących niezmiernie charakterystyczny element życia seksualnego w społeczeństwach magicznego kręgu światopoglądowego.

Obok magii z życiem seksualnym ludów pierwotnych wiąże się mniej lub więcej rozbudowana symbolika, w której płciowość albo służy jako znak do wyrażenia innej treści, bądź staje się przedmiotem i punktem odniesienia dla treści innego znaku. Istotne jest to, że za pomoca magii i symboliki płciowość i jej funkcje zostają włączone w bardzo szeroki kontekst zbiorowego życia społeczeństw pierwotnych i stają się jego nieodłączną częścią o doniosłej roli społecznej.

Pozostaje jeszcze jeden fundamentalny aspekt moralności seksualnej ludów pierwotnych, na które etnologia zwraca uwagę, aczkolwiek w dostępnych danych trudno się zorientować, czy występuje on z równą siła w tak szerokim zasięgu, jak omówione poprzednio. Podkreślone zostało silne zakorzenienie moralności seksualnej w światopoglądowej postawie ludów pierwotnych i wypływająca stąd szeroka sieć rozgałęzień wpływów płciowości na całość życia społecznego tych ludów. Z tą rozbudowaną ,ideologią" seksualizmu pozostaje w pewnym rozdźwięku umiar i społeczna dyscyplina rządząca życiem seksualnym w społeczeństwach pierwotnych, brak erotyki i skoncentrowanie go na celach prokreatywnych. Bastide tłumaczy to materialnymi warunkami egzystencji człowieka pierwotnego. „Na najbardziej prymitywnym poziomie... egzystencja człowieka nieżonatego jest niemożliwa i dlatego... małżeństwo (czy rodzina) jest według określenia Lévi-Straussa ,spółką produkcyjną" w sensie zarówno biologicznym, jak i produktów żywnościowych. Płciowość nie ma tu innej funkeji jak wydanie na świat dzieci" 53. Podporządkowania życia seksualnego dobru gatunku i jego trwałości dopatrują się etnologowie również w często wśród ludów pierwotnych stosowanej zasadzie, że dopiero urodzenie się dziecka scala małżeństwo w trwałą

s2 Mohr, dz. cyt., 136-137.

53 Dz. cyt., 88. 
wspólnotę życiową. Kobieta bezpłodna uważana jest za bezwartościowy przedmiot, jej płciowość pozbawiona jest właściwego sensu ${ }^{54}$. Gdy ten brak wychodzi na jaw w małżeństwie, zostaje ono przez męża unieważnione, a los żony bywa różny. Albo zostaje oddalona, albo wymieniona na inną, zwłaszcza w małżenstwach, w których małżeństwo dochodzi do skutku za okupem, albo też - w społeczeństwach poligamicznych bezpłodność jednej żony staje się bezpośrednią racją wzięcia za żonę drugiej kobiety. Z tych samych źródeł bierze początek moralna ochrona ciężarnych kobiet przejawiająca się w różnych formach moralnego tabu.

W zakończeniu tego punktu rozważań można by więc sformułować ogólną opinię, że społeczeństwa pierwotne, jeżeli nie powszechnie, to przynajmniej w szerokim zakresie zajmują wobec życia seksualnego postawę, którą Bastide określa jako „płciowość bez erotyzmu” 55.

Światopoglądowe podstawy moralności seksualnej ludów pierwotnych i powiązanie tej moralności z głównymi kategoriami życia społecznego ukazują świat naczelnych idei, motywów i celów, we wnętrzu którego ta moralność jest osadzona i z którego czerpie właściwą sobie treść ideową. Najważniejszym jednak elementem tej treści są oceny i normy regulujące seksualne zachowania się człowieka pierwotnego. Moralność seksualna przybiera w nich postać praktyczną, skierowaną na sytuacje życia codziennego i dlatego najwyraźniej rysującą się w świadomości moralnej i społecznym obyczaju tych ludów. Stwarza to niezmiernie skomplikowany system zasad postępowania, z którego zostaną wybrane elementy najbardziej interesujące ze stanowiska naszego tematu, zacieśnionego do przedmałżeńskiej etyki seksualnej.

U ludów pierwotnych charakterystyczną postać przybiera zjawisko wstydu. Rozpatrując rzecz od strony danych etnologicznych stwierdzić należy, że ubranie nie jest powszechnym elementem poczucia wstydu, mniejszy zaś lub większy stopień obnażania się określonych ludów nie oznacza wcale eo ipso proporcjonalnej utraty wstydu. Owszem, u ludów, które chodzą nago lub prawie nago ograniczając ubiór do skąpej przepaski biodrowej, poczucie wstydu występuje nieraz w bardziej wyraźny sposób, szczególnie $\mathrm{w}$ ich codziennym zachowaniu, aniżeli u ludów „ubranych”. Holender J. M. Schuwer już w XIX w. wyraził pogląd, że niemoralność u ludów afrykańskich wzrasta proporcjonalnie do wzrostu stosowanego przez nich okrycia. Zgadza się z nim Anglik Austin na podstawie swych obserwacji poczynionych w czasach długich podróży po Afryce, podobnie wyraża się Niemiec Koch-Grünberg o brazylijskich Indianach ${ }^{56}$. Opinię tę podtrzymują także współcześni etnologowie, np.

54 Bastide, Rzeczywistość plci u ludów pierwotnych, 60-61.

55 Dz. cyt., 61. 56 Mohr, Die christliche Ethik..., 139-141. 
B. Malinowski, odnośnie do Trobriandczyków ${ }^{57}$, tak że można ją przyjąć jako pewną. Poczucia wstydu u ludów pierwotnych nie zaprzeczają również fakty, że niektóre $\mathrm{z}$ nich, chodząc zasadniczo $\mathrm{w}$ odpowiednim stroju, rozbierają się do naga przy wykonywaniu określonych czynności, np. przy kąpieli (Ibo - Nigeria), pracy w polu (Bali - Kamerun) lub podczas deszczu (Bontok - Igorroto na wyspie Luzon). Notuje się również fakty, że u pewnych ludów większe poczucie wstydliwości występuje u mężczyzn, aniżeli u kobiet. Np. u Bataków na Sumatrze do kąpieli kobiety rozbierają się do naga, mężczyźni zaś stosują przepaski biodrowe; podobne zjawiska występują w środkowej Afryce ${ }^{58}$. Pod pewnym względem więcej wstydliwi są Trobriandczycy, aniżeli Trobriandki ${ }^{59}$. Są też ludy, które nie wstydząc się nagości w obcowaniu między sobą zdradzają wyraźne objawy wstydu przy zetknięciu się z Europejczykami ${ }^{60}$. Obrazu tego nie można zbytnio idealizować, mimo wszystko uprawniony wydaje się ostateczny wniosek, że poczucie wstydu jest z niewielkimi wyjątkami zjawiskiem powszechnym wśród ludów pierwotnych. Poczucie to nie jest związane w sposób konieczny ze zwyczajem okrywania ciała; w swych przejawach zewnętrznych przybiera nader zróżnicowane formy, wyraża się zaś głównie w dużej powściągliwości i umiarze, jaki członkowie społeczeństw pierwotnych wykazują na co dzień w zewnętrznym zachowaniu się i w mowie odnośnie do anatomii i funkcji płciowych człowieka, krótko mówiąc nie eksponuje się u nich płciowych zróżnicowań budowy człowieka, nie zwraca się na nie uwagi, unika się objawów podniecenia płciowego w życiu zbiorowym i nie mówi się o tym.

Jak sprawa ubioru, tak samo i społeczny rozdział płci nie ma bezpośredniego związku ze wstydliwością czy jej brakiem. Są bowiem takie szczepy, które rygorystycznie zakazują wspólnego przestawania osób różnej płci, a mimo to wzajemne relacje seksualne są dość swobodne (Arapesh), inne nie mają tego podziału, a mimo to cenią wstydliwość i czystość przedślubną ${ }^{61}$.

Dokładniejszego omówienia domaga się natomiast świadomość moralna ludów pierwotnych odnośnie do seksualnego pożycia przedmałżeń-skiego. Jeżeli jako zasadnicze kryteria przyjmie się nieuznawanie lub uznawanie jego dopuszczalności, w świadomości moralnej społeczeństw pierwotnych występuje wyraźna linia podziału na dwie moralności: surowszą i tolerancyjną. Można bowiem wymienić cały szereg ludów pierwotnych, najczęściej wyznających wiarę w istnienie bóstw trans-

\footnotetext{
57 Malinowski, Zycie seksualne dzikich..., 385-386, 406-420.

58 Mohr, Die christliche Ethik..., 141-142.

59 Malinowski, Życie seksualne dzikich..., 386.

60 Mohr, dz. cyt., 144.

${ }_{61}$ Dz. cyt., $125-129$.
} 
cendentnych, które pojmują pożycie seksualne przedmałżeńskie jako zło moralne, gdyż obrażające bóstwo. Co więcej, właśnie w związku z tá normą zaznacza się duża rola wspomnianego już mitu o pierwszym grzechu cielesnym, który wprowadził nieład moralny w życie seksualne ludzi. Pożycie przedmałżeńskie stanowi jakby ponowienie tego zła, dla.tego pociąga za sobą wielki grzech i grozi nieszczęściem dla całej społeczności. Jeżeli nawet nie u wszystkich ludów idea współudziału przedmałżeńskich stosunków płciowych $\mathrm{w}$ pierwszym grzechu ludzkości występuje w tak wyrazistym świetle, jak u szczepu Bubi, to jednak -.. ogólnie rzecz biorąc - leży ona u źródeł przeświadczenia tych ludów o wysokiej wartości dziewictwa i zakazu wszelkiego przedmałżeńskiego pożycia seksualnego. Ona też łłumaczy surowość kar społecznych, jakimı u wielu ludów okłada się łamiących to szczepowe tabu. Skazuje się ich bowiem oboje, alko samą dziewczynę na śmierć, gdzie indziej zabija siẹ, nieślubne dziecko, wyłącza się winowajeów ze wspólnoty szezepowej, w najlepszym wypadku zobowiązuje się ich do wypłacenia odpowiednich grzywien. Tak wygląda sprawa u Bubi (Fernando Poo), Weddów (Cejlon), Tumbuka (płd. Afryka), Ruanda (jezioro Wiktoria), Seedajaków (Borneo) i wielu innych ${ }^{62}$.

Istnienia normy wstrzemięźliwości przedmałżeńskiej $\mathrm{w}$ świadomości moralnej ludów pierwotnych dowodzą także zwyczaje ludów Baganda (jezioro Wiktoria) i Bergdama (płd.-zach. Afryka). Tylko dziewice strzegą u nich ognia, podobnie jak Westalki w starożytnym Rzymie ${ }^{63}$.

Taką samą treść moralną zawierają tabu nakazujące wstrzemięźliwość płciową podczas inicjacji szczepowych oraz bardzo charakterystyczny zwyczaj tzw. nocy Tobiaszowych. U pewnych mianowicie szczepów nowożeńcy winni się wstrzymać z zapoczątkowaniem życia seksualnego przez jedną noc (na wyspie Samoa, u Tinguianów na Filipinach), przez trzy noce (Konso w Abisynii), a nawet 6 miesięcy (Ankwe - Nigeria) czy jednego roku (Capaia - Ekwador) ${ }^{64}$.

Etnologia zna jednak równie spory poczet ludów pierwotnych, których świadomość moralna uznaje dopuszczalność pożycia przedmałżeńskiego w granicach odpowiedniego obyczaju społecznego. Wymownym pod tym względem przykładem jest stan obyczajowości panującej wśród Trobriandczyków, ludu papuo-melanezyjskiego, opisany ze wszystkimi szczegółami przez Malinowskiego w niejednokrotnie już przytaczanej pracy Życie seksualne dzikich. Charakteryzując przedmałżeńską moralność tego ludu autor podkreśla dużą swobodę moralnych opinii i obycżajów Trobriandczyków. I tak uznają oni wezesną inicjację seksualną mło-

62 Mohr, dz. cyt., $111-116$.

63 Dz. cyt., 96.

64 Tamże. 
dzieży nawet przy zachęcie ze strony rodziców, praktykują w życiu szczepowym formy rekreacyjne, przede wszystkim wspólne zabawy młodzieży męskiej i żeńskiej, których rytuał prowadzi w zakończeniu do seksualnych zbliżeń uczestników, a wreszcie utrzymują na terenie wsi tzw. „domy kawalerów”, w których poszczególne pary współżyją ze sobą seksualnie, aczkolwiek z zachowaniem zewnętrznego umiaru, bez zbiorowych orgii i innych seksualnych ekscesów ${ }^{65}$. Pojęcia i obyczaje Trobriandczyków w zakresie przedmałżeńskiej etyki seksualnej nie należą bynajmniej do rzadkości. Wiele innych ludów przynależnych na ogól do immanentno-magicznego kręgu światopoglądowego hołduje po-dobnym zasadom i obyczajom. Wobec tego szeroko wśród ludów pierwotnych rozpowszechnioną aprobatę przedmałżeńskiego pożycia seksualnego młodzieży trzeba uznać za bezsporny fakt etnologiczny.

W jednym wszakże punkcie ta swoboda pojęć moralnych ulega ograniczeniu. Niezależnie bowiem od uznania przez wspomniane szczepy pożycia seksualnego u młodzieży za moralnie dopuszczalne, wszystkie w ogóle społeczeństwa pierwotne (z bardzo nielicznymi wyjątkami) uważają stosunki kazirodcze, czyli między rodzeństwem, u niektórych ludów także między bliskimi krewnymi, za wielki grzech i obrazę bóstwa ${ }^{66}$.

Z dostępnych źródeł etnologicznych trudno się natomiast zorientować, jak się przedstawiają opinie moralne ludów pierwotnych odnośnie do nadużyé czy zboczeń seksualnych. Malinowski informuje, że badani przez niego Trobriandczycy potępiają takie nadużycia seksualne jak onanizm, homoseksualizm czy sodomia ${ }^{67}$. Ustalenia Malinowskiego odnośnie do onanizmu i homoseksualizmu w szerszym jeszcze kontekście, przede wszystkim w odniesieniu do religijno-transcendentnego kręgu kulturowego potwierdza Mohr ${ }^{68}$. Dane te pozwalają przypuszczać, ̇̇e moralność seksualna społeczeństw pierwotnych ocenia tego rodzaju zachowania zdecydowanie negatywnie, ale na temat powszechności tych opinii trudno sobie urobic ostateczny sąd.

Pozostają jeszcze do sformułowania ogólne refleksje nad zarysowanym obrazem moralności seksualnej w świadomości ludów pierwotnych.

Nie trzeba przypominać, że specyfika tematu niniejszej pracy zmusiła do zreferowania tylko niektórych elementów tej moralności i w bardzo ogólnym ujęciu. Ale już ten szkicowy zarys dowodzi, że uzyskany tą drogą materiał ma dla etyki seksualnej znacznie bogatszą wymowę aniżeli sądzi na ten temat Böcle ${ }^{69}$. Obok niewątpliwego faktu, że życie sek-

65 Malinowski, Życie seksualne dzikich..., 48-66.

66 Mohr, dz. cyt., 122-125.

67 Malinowski, Życie seksualne dzikich..., 400-406.

68 Mohr, dz. cyt., 64, 66, 128, 136-137, 152.

69 Böckle, Ethos der Liebe, 21. 
sualne społeczeństw pierwotnych podlega reglamentacji ze strony moralności, odsłania się przed nami bogaty świat składających się na tę moralność idei i intuicji moralnych, których poznanie ma niemałe znaczenie dla należytego ustawienia i naświetlenia podstawowych zagadnień etyki seksualnej.

Raz jeszcze w formie końcowego wniosku podkreślić należy wcześnie.j postawione twierdzenie, że społeczeństwa pierwotne wykazują jedną radykalną różnicę w pojmowaniu moralności przedmałżeńskiej. Na tym odcinku zaznacza się u nich wyraźny dualizm pojęć i zasad: nakaz wstrzemięźliwości przedmałżeńskiej znajduje swoją przeciwwagę w moralnej akceptacji pożycia seksualnego przedmałżeńskiego i braku moralnego ideału dziewictwa. Niektórzy etnologowie włączają tę przeciwstawność w kontekst dwu odmiennych orientacji światopoglądowych: transcendentno-religijnej i immanentno-magicznej. Pogląd to wysoce prawdopodobny, ale nawet niezależnie od światopoglądowych uwarunkowań istnienie dwu typów moralności seksualnej, surowszej i tolerancyjnej, nie ulega wątpliwości.

$\mathrm{Na}$ tle tego stanu rzeczy widać wyraźnie, jak wielkim uproszczeniem sprawy jest wiązanie etosu dziewictwa i czystości przedmałżeńskiej z kulturą czy religią chrześcijańską, a jeszcze bardziej przedstawianie tendencji do seksualnej tolerancji przedmałżeńskiej jako osiągnięcie „,współczesnego człowieka". Swiadomość moralna najstarszych historycznie ludzi, o których posiadamy sprawdzoną naukową wiedzę, zna obie te postawy. A zatem w perspektywie dziejów ludzkości współczesne liberalne tendencje są tak samo „stare”, odwieczne, jak i moralność przedmałżeńskiej dyscypliny i powściągu. Ale to nie przesądza w niczym sprawy moralnej wartości zarówno jednej, jak i drugiej postawy. Dowodzi tylko, że kryteriów ,postępu” czy „,nowoczesności” w zakres“e etyki seksualnej trzeba szukać na innej drodze, aniżeli w kategoriach „,dziś” i „wczoraj”, „dawne” i „,współczesne”.

Moralność seksualna ludów pierwotnych zawiera w sobie także liczne elementy, które rzucają światło na stosunek, jaki w intuicjach tych ludów zachodzi pomiędzy sferą pliciowości a rozumną świadomością człowieka. Najwięcej do myślenia daje tu fakt istnienia u części ludów pierwotnych nakazu wstrzemięźliwości przedmałżeńskiej. Jeżeli nawiasem dodamy, że również na małżonków moralne tabu nakłada u wielu ludów krótsze lub dłuższe okresy obowiązkowej wstrzemięźliwości płciowej ${ }^{70}$, w takim razie uzasadniony wydaje się wniosek, że płciowość $\mathrm{w}$ rozumieniu tych ludów nie jest żywiołem determinującym w niepohamowany sposób zachowanie się człowieka, ale siłą pozostającą pod kontrolą jego świadomych i rozumnych decyzji. Choć przeświadezenie

70 Por. Mohr, dz. cyt., 88-96; Malinowski, dz. cyt., 199. 
to nie występuje w formie jasnej refleksji nad samym sobą, niemniej jednak zawiera się implicite w treści uznawanych przez ludy pierwotne norm moralnych jako konieczny warunek ich istnienia i funkcjonowania. Idea nieprzepartej mocy popędu seksualnego i jego decydującej roli w określaniu norm moralnych nie jest przeto zjawiskiem ogólnoludzkim. Pojawia się ona dopiero w późniejszych etapach kulturalnego rozwoju ludzkości i jest owocem określonych ideologii filozoficznych. W takim razie dążenie do emancypacji seksu i przekształcenia go w autonomiczna wartość międzyosobową nie jest ani elementarnym doświadczeniem ludzkości, ani doświadczeniem powszechnym, ale tendencją czerpiącą inspirację ze źródeł określonych rozwojem cywilizacyjnym człowieka oraz odpowiednich koncepcji filozoficznych. Mimo to niesie z soba ukazanie aspektów życia seksualnego człowieka odmiennych od doświadczenia moralnego ludów pierwotnych, i w tym charakterze winna byc uwzględniona w rozważaniach nad etyką seksualną.

\section{ZASADY ROZUMOWE ETYKI SEKSUALNEJ}

Zgodnie z wcześniej daną zapowiedzią przedmiotem aktualnych rozważań staną się trzy podstawowe zagadnienia filozoficzno-etyczne, któ rych rozwiązanie prowadzi do ustalenia zasad rozumowych niezbędnych przy budowie normatywnego systemu etyki seksualnej. Określają one ontyczny status natury człowieka, źródła moralnej specyfikacji aktu ludzkiego, a wreszcie charakter i moc obowiązująca opartych na nich ocen i norm. Zasady te określają fundamenty filozoficznej wizji moralności i dlatego wchodzą w zakres etyki ogólnej, która jest powołana do ich sformułowania. Można by zatem poprzestać na ich prostym wyliczeniu. Ponieważ jednak zostały one zakwestionowane przez wielu autorów z obozu etyki chrześcijańskiej właśnie w zastosowaniu do etyki seksualnej, dlatego trzeba do nich w ramach tej etylki powrócić i rozważyć, jaką wartość teoretyczną przedstawiają postawione nad nimi znaki zapytania. Krytyczna analiza wysuniętych zarzutów umożliwi równocześnie jaśniejsze sprecyzowanie zajętego tu stanowiska. Oczywiście zamierzone rozważania zostaną ograniczone do koniecznego minimum, gdyż mimo wszystko mają charakter na wskroś polemiczny i zmierzają tylko do umocnienia gruntu, na którym zostanie oparta normatywna konstrukcja etyki seksualnej. Nie wydaje się rzeczą celową pomijać milczeniem kontrowersyjne sprawy współczesnej etyki seksualnej, ale podejmują je trzeba to czynić w odpowiednich proporcjach. 


\section{a) Natura a kultura i historia}

Wszyscy autorzy, którzy odrzucają prawo naturalne i opartą na nim moralność seksualną, czynią to w imię jednej, zgodnie przyjmowanej racji: nie ma jakiejś wspólnej wszystkim ludziom i niezmiennej natury, która mogłaby stanowić źródło i podstawę dla takiego prawa ${ }^{71}$. Jeżeli nawet dadzą się wykryć w treści człowieczeństwa jakieś elementarne struktury, to i tak są to struktury dynamiczne, otwarte na ciągłe radykalne przeobrażanie się w procesie historycznych przemian i kulturowego rozwoju ${ }^{72}$. Moralność seksualna jest zatem dziełem wielkiego mechanizmu dziejów ludzkich, a przeto kształtuje się zgodnie z panującymi historycznie układami społecznych warunków. Natura służy co najwyżej za elastyczne tworzywo tych procesów, nie określa natomiast rządzących nimi praw i nie stanowi źródła zasad moralnych.

Zarysowane tu spojrzenie na naturę ludzką i jej rolę w formowaniu moralności seksualnej nie jest wyłącznie własnością autorów chrześcijańskich. Zapatrywanie to podzielają oni wspólnie z etykami laickimi, od których je zresztą w dość spóźnionym terminie przyjęli. Toteż przeciwstawienie natury i kultury oraz natury i historii należy dziś do nader rozpowiszechnionych wątków rozważań nad podstawami etyki seksualnej.

Licząc się z tym faktem tym bardziej wydaje się rzeczą wskazaną zastanowić się, na jakich przesłankach opiera się to rozumowanie. Otóż uderza fakt, że u wypowiadających się w tym duchu autorów brak jesi szerszej na ten temat dokumentacji. Zaprzeczenie stałych i wszystkim ludziom wspólnych struktur istotowych traktowane jest jako pewnik współczesnej nauki i filozofii, który nie wymaga osobnych uzasadnień. Nieprzyjmowanie tego pewnika stanowi dowód filozoficznego zacofania i naiwnego myślenia ${ }^{73}$, bądź esencjonalno-abstrakcyjnego podejścia do rzeczy ${ }^{74}$. Jest to $z$ całą pewnością niewystarczający ze stanowiska naukowego sposób rozstrzygnięcia postawionego zagadnienia ze strony wspomnianych autorów, tym bardziej że nie cytują źródeł, które zawierają niezbędną dla ich tezy dokumentację. Toteż nie widać potrzeby bezpośredniej z nimi polemiki. Pozostaje tylko jedno, mianowicie we własnym zakresie podjąc próbę uzupełnienia wspomnianych luk w ich wywodach i wskazać na zasadnicze źródła, z których ten typ filozofowania czerpie swoje natchnienie. Na podstawie danych historii filozofii w ogóle, a hi.storii etyki w szczególności można przyjąć, że negacja stałej i powszech-

71 Antoine, Sens płciowości i poszukiwanie etyki, 270; David, Christliche Sexualmoral in einer säcularisierten Welt, 26-27.

72 Böckle, Ethos der Liebe, 26.

73 Antoine, Morale sans anthropologie, Paris 1970, 10.

74 F. Furger, Zur Begründung eines christlichen Ethos - Forschungstendenzen in der katholischen Moraltheologie, w: Theologische Berichte, B. IV, Zürich 1974, 54. 
nej natury ludzkiej jako podstawy prawa naturalnego bywa najczęściej usprawiedliwiana na dwa sposoby. Jeden $\mathrm{z}$ nich polega na odwołaniu się do różnych faktów dostarczonych głównie przez etnologię i historię kultury. Dowodzą one, że w świadomości moralnej ludów zarówno cywilizowanych jak i niecywilizowanych doszło do znacznego zróżnicowania zasad moralnych w bardzo szerokim zakresie działań ludzkich. Drugi sposób uzasadniania negacji powszechnej i stałej natury sięga korzeniami do ogólnofilozoficznych założeń i wychodząc z empirycznej teorii poznania całą rzeczywistość, a więc świat i człowieka interpretuje od strony ich zjawiskowych, czasoprzestrzennych aspektów. Interpretacje te ulegają zróżnicowaniu odpowiednio do kierunku, na gruncie którego bywają wypracowane. Współcześnie dzieje się to najczęściej na bazie pozytywizmu, egzystencjalizmu, ewolucjonizmu, scjentyzmu lub naturalizmu, co w etyce prowadzi do zrelatywizowania pojęcia natury jako podstawy moralności. Oba te tory rozumowania często się ze sobą zbiegają. W tym wypadku relatywistyczne założenia filozoficzno-etyczne szukają potwierdzenia w danych etno-historycznych, lub na odwrót uogólnienia tych danych inspirują się tezami filozoficznymi.

Czas przejść do krytycznego naświetlenia obu naszkicowanych źródel argumentacji. Szczególowe przedstawienie oceny krytycznej wyprowadziłoby nas poza ramy etyki seksualnej. Wystarczy jednak wypunktować przynajmniej najważniejsze zastrzeżenia, aby się przekonać, na jaks kruchych podstawach opiera się kontestacja powszechnej i niezmiennej natury ludzkiej.

Niepodobna przeczyć, że w świadomości moralnej społeczeństw ludzkich na wszystkich szczeblach ich kulturowego rozwoju wystepuje w odniesieniu do wielu kategorii działań większe lub mniejsze zróżnicowanie pojęć i zasad moralnych. Etnologia moralności seksualnej dostarcza wymownej ilustracji tego twierdzenia. Równocześnie jednak - biorąc pod uwagę całokształt dostępnych danych etnologicznych i historycznych - można wykazać, że zróżnicowanie to w żadnym wypadku nie sięga tak głęboko, aby naruszało sam rdzeń moralności w postacı ogólnoludzkiej fundamentalnej wspólnoty naczelnych idei moralnych, na których wznosi się gmach funkejonujących w świadomości społeczeństw ludzkich systemów moralnych. Oprócz tego przypomnieć należy, że zróżnicowanie pojęć moralnych w świadomości społeczeństw ludzkich rzutuje bezpośrednio tylko na tę ich cechę, mocą której pojęcia te uchodzą za powszechne, czyli znane wszystkim ludom w czasie i prze-strzeni. Jeżeli jednak te same pojęcia uzna się za elementy obiektywnego, niezależnie od ludzkiego poznania danego porządku moralnego (a sa racje, które za tym przemawiają), w takim razie różnice występujące w ich treści nie dotyczą bezpośrednio, a tym samym nie dowodzą zmian 
zachodzących ewentualnie $\mathrm{w}$ obrębie samej na obiektywnych podstawach opartej moralności. Istnienie różnic moralnych w pojęciach i zasadach można $\mathrm{w}$ takim założeniu tłumaczyć jako wynik nieadekwatnego poznania przez poszczególne ludy obiektywnego porządku moralnego, w konsekwencji czego pojawiły się w świadomości tych ludów błędne przekonania moralne. Innymi słowy fakt częściowego zróżnicowania pojęć moralnych sam ze siebie nie dowodzi tezy o zmiennym charakterze moralności jako takiej.

Owszem, dla rozstrzygnięcia pytania, na jakich podstawach, zmiennych czy niezmiennych, opiera się moralność, większą siłę dowodowa posiada wspomniana przed chwilą wspólnota podstawowych zasad moralnych, której istnienie $\mathrm{w}$ odpowiednim zakresie wykazuje również etnologia. Ta bowiem zastanawiająca zgodność rodzaju ludzkiego nie może być w pełni wyjaśniona, jak tylko w założeniu, że we wszystkich ludziach istnieje jakieś obiektywne dane, jednoczące ich sedno, czyli jakaś wspólna ludziom i niezmienna natura. A zatem dane etno-historyczne przemawiają bardziej przekonująco za przyjęciem teorii natury, aniżeli za jej odrzuceniem ${ }^{75}$.

W tym stanie rzeszy więcej prawdopodobne wydaje się przypuszczenie, że właściwe źródło zakwestionowania niezmiennej natury ludzkiej jako podstawy moralności seksualnej kryje się w filozoficznej warstwie motywacji przytaczanej na rzecz tego stanowiska. Jak wspomniano, sięga ona swymi korzeniami aż do empirystycznej teorii poznania, przekształca się z kolei w fenomenalistyczną koncepcję człowieka konkretnego i historycznie zmiennego, a w końcu przybiera postać relatywistycznej teorii moralności. Stąd już krok tylko do odrzucenia stałej podstawowej struktury moralnej, czyli natury ludzkiej.

Jeżeli diagnoza o filozoficznym rodowodzie kontestacji natury ludzkiej jest słuszna, w takim razie dyskusja z reprezentującymi ją autorami zarówno chrześcijańskiej, jak i laickiej orientacji światopoglądowej jeszcze w wyższym stopniu wykracza poza ramy etyki seksualnej i etyki w ogóle, aniżeli w sprawie empirycznych źródeł tej kontestacji. Jest to w gruncie rzeczy spór teoriopoznawczy i antropologiczny, jeden z istotnych elementów rozgrywającego się na naszych oczach konfliktu humanizmów, których zmagania rzutują w dogłębny sposób również na etykę seksualną. Toteż nie będziemy wdawać się w krytykę empirystycznych czy fenomenalistycznych tez i uzasadnień. Zadanie to spełniają inne części składowe systemu filozofii chrześcijańskiej, przede wszystkim tomistyczna wersja teorii poznania i antropologii. Opierając się na ich ustaleniach trzeba uznać filozoficznie zorientowaną argumentację prze-

75 Por. T. Slipko, Zarys etyki ogólnej, 159-170. 
ciwko pojęciu natury ludzkiej za równie chybioną, jak i jej etno-historyczną odmianę. W każdym razie, cokolwiek by się sądziło o teoretycznej wartości tego poglądu, pozostaje prawdą, że empiryzm teoriopoznawcy i oparta na nich fenomenalistyczna wizja człowieka (u autorów chrześcijańskich najczęściej egzystencjalistyczna lub historycystyczna, u autorów laickich indywidualistyczna lub kolektywistyæzna) jest we współczesnym świecie filozoficznym tylko jedną z interpretacji, propozycją, której prawomocność jest zależna od przytaczanych na jej rzecz uzasadnień. Przedstawienie jej jako współcześnie jedynie liczącej się i obowiązującej filozofii człowieka jest pozbawionym wszelkich podstaw roszczeniem. U autorów chrześcijańskich oznacza to tak radykalna zmianę fundamentów etyki filozoficznej, że równa się ich przejściu na stronę dotychczasowych przeciwników filozofii chrześcijańskiej. W zreferowanych wypowiedziach tych autorów mało się o tym przejściu mówi, choć trudno przypuszczać, aby nie zdawali sobie oni z tego sprawy. Gąszcz niedomówień i półsłówek względnie wciąż powtarzane hasło o konieczności pójścia za głosem współczesnej nauki i postępu, jak się zdaje, służy tylko za dymną zasłonę, poza którą kryje się odwrót tych autorów od całej chrześcijańskiej tradycji filozoficznej.

Krytyczna ocena opinii negującej istnienie powszechnej i niezmiennej natury człowieka ukazała w ogólnych przynajmniej zarysach istotne mankamenty tego stanowiska, ale nie we wszystkich punktach była ona kompletna. Szczególnie w sprawie teoriopoznawczych i antropologicznych założeń tej negacji ograniczyła się tylko do zasygnalizowania problemu nie dając jego pozytywnego naświetlenia. Pewnym uzupełnieniem jednostronności tego ujęcia będzie krótkie i z konieczności sumaryczne zarysowanie tradycyjnego pojmowania natury ludzkiej, na którym etyka chrześcijańska buduje podstawy moralności.

Najpierw podkreślić należy, że material do skonstruowania tego pojęcia umysł ludzki czerpie z doświadczenia zewnętrznego i wewnętrznego. Ukazuje ono człowieka jako byt psychofizyczny, duchowo-psychiczny, konkretny i ujednostkowiony, pozostający w stałym związku z otaczającą go rzeczywistością przyrodniczą i społeczną. W tym wymiarze człowiek podlega zmianom i poddany jest procesom historycznego rozwoju.

Dzięki duchowym własnościom intelektu człowiek może w materiale konkretnych wrażeń dostarczonych mu przez doświadczenie wyszukać ogólne elementy, które przysługują na zasadzie jednoznaczności lub podobieństwa odpowiednim klasom przedmiotów (gatunkom, rodzajom, kategoriom transcendentalnym, czyli ponadrodzajowym), aby przekształcić je następnie w tzw. powszechniki, czyli pojęcia powszechne. $\mathrm{Na}$ tej też tylko drodze może on dotrzeć do fundamentalnej struktury własnego człowieczeństwa, zwanej powszechnie ,naturą ludzką”. 
Wynikają stąd dwa wnioski. $1^{\circ}$ Warunkiem koniecznym dla urobienia sobie adekwatnego filozoficznego pojęcia ,natury" jest teoria pojęć powszechnych jako podstawy różnego od zmysłów myślenia racjonalnego. A zatem filozof, który uznaje tylko poznanie zmysłowe, a umysłowe interpretuje wyłącznie jako przedłużenie poznania zmysłowego i sądzi, że jest ono ważne tylko w zakresie tegoż poznania na zasadzie uogólnienia indukcyjnego, nie może dojść do wykrycia w człowieku jego natury. Przyczyną tego stanu rzeczy jest jednak niedoskonałość stosowanych przez niego narzędzi poznawczych w postaci nieadekwatnej teorii poznania. Ale z faktu, że filozof ten nie dociera do natury ludzkiej, nie wynika, że natury tej nie ma. Ona jest i daje się poznać, ale pod warunkiem oparcia się na adekwatnej teorii poznania i filozofii bytu, w tym też człowieka.

„Natura ludzka” oznacza tedy rzeczywistość, która dostępna jest poznaniu ludzkiemu na wyższym stopniu, aniżeli poznanie zmysłowe. Pojęcia natury tworzone $w$ obrębie poznania zmysłowego nie siegaja do istoty rzeczy, a przede wszystkim mają treść zgoła inną, aniżeli racjonalne pojęcie natury przyjmowane przez klasyczną filozofię chrześcijanską. Często określa się ten typ poznania jako ,metafizyczny”, ,pozazmysłowy". W gruncie rzeczy jest to poznanie jak najbardziej ,endofizyczne”, czyli ,wewnątrzfizyczne”, gdyż zakłada poznanie zmysłowe i z niego czerpie właś`iwe sobie powszechnikowe treści poznawcze.

$2^{\circ} \mathrm{Na}$ pełną rzeczywistość bytu ludzkiego składają się elementy zarówno zmienne, jak i niezmienne. Dzięki pierwszym człowiek jest bytem historycznie uwarunkowanym, natomiast elementy niezmienne czynią zeń byt ponadhistoryczny i niezmienny. Otóż natura ludzka wyraża właśnie tę odwieczną, fundamentalną strukturę człowieka. Ale z kolei ta fundamentalna struktura człowieka może być widziana albo w aspekcie statycznym, albo dynamicznym. Filozofia chrześcijańska z pojęciem natury wiąże stale aspekt dynamiczny. Pojmuje ją bowiem jako zasadę działania właściwego człowiekowi jako czlowiekowi. Toteż na całościowo ujmowaną rzeczywistość natury składają się nie tylko istotowe składniki człowieczeństwa, duch i materia, zespolone w jedność substancjalnego bytu. W jej skład wchodzą także wszystkie uzdolnienia człowieka do działania, czyli jego ,władze" na wszystkich poziomach struktury człowieczeństwa: biologicznej (wegetatywnej), zmysłowej i duchowej. Szczególnie duchowe uzdolnienia człowieka decydują o jego specyficznie „ludzkiej naturze”. Należą do nich rozum i wola, za pomocą których człowiek działa jako człowiek, czyli jako byt samoistny, samowiedny i samowładny. Wszystko to zaś można zawrzeć w jednym zdaniu: człowiek działa jako osoba.

Nie wchodząc w zagadnienie, na czym polega istotny sens pojęcia 
osoby, jej swoistej określoności i specyfiki, trzeba jednak podkreślić, że natura człowieka jako zasada działania wyznacza równocześnie zasadnicze kierunki jego działania w odniesieniu do innych bytów. Dynamizm jego natury zwraca go najpierw w stronę przyrody, w skład której wchodzą wszystkie rzeczy i istoty nierozumne, następnie ku innym ludziom, a wreszcie w stronę Bytu transcendentnego, czyli Boga. Relacje łączące osobę z innymi ludźmi mogą przybierać bądź postać ,międzyosobową", gdy zachodzą między osobami jako równymi sobie i od siebie ontycznie niezależnymi istotami, bądź ,społeczną", kiedy wiążą określone jednostki w grupy społeczne. W tym założeniu poszczególne osoby stają sį członami całości i pozostają w zależności od nich, mimo że całość ta swój ostatateczny sens i rację istnienia znajduje w osobach, których rozwojowi i doskonaleniu ma służyć.

Ogól wymienionych elementów scalonych w jedną, aczkolwiek heterogenną strukturę określa właściwą etyce chrześcijańskiej wizję natury ludzkiej stałej i powszechnej, gdyż wypływa ona z samej treści człowieczeństwa i nie da się od niej oderwać. Dlatego natura stanowi integralną część ludzkiej rzeczywistości w każdym człowieku z osobna wziętym i całej ludzkości na wszystkich etapach jej rozwoju. Skupia w sobie i syntetyzuje wszystko, co w człowieku najgłębsze i niezależne od warunków miejsca i czasu, co stanowi stałą i absolutną, czyli niezmienną i powszechnie ważną organizację fundamentalnych składników człowieczeństwa i przekształca je w wewnętrznie zwartą i uporządkowana jedność. Obraz ten jest dziełem filozoficznej refleksji nad człowiekiem wypracowanym przy pomocy właściwych filozofii metod myślenia. Toteż wbrew sugestiom Antoine'a ${ }^{76}$ jego prawomocności nie naruszają osiągnięcia nauk szczegółowych, ponieważ zajmują one w swych badaniach zjawiskowy kąt widzenia i formułują sądy, które dotyczą tylko cząstkowych aspektów rzeczywistości właściwej przyrodzie i człowiekowi. Pomyłki tego autora, jak wielu innych, wynikaja stąd, że nie doceniają ani odrębności i swoistości myślenia filozoficznego na skutek zbyt uproszczonego, na gruncie empiryzmu i pozytywizmu urobionego poglądu na ludzki intelekt i jego możliwości poznawcze.

Pozostaje jeszcze jeden punkt do sprostowania. W ujęciu omówionych przez nas autorów, jeżeli się w ogóle dopuszcza jakąś myśl o naturze człowieka, to tylko w znaczeniu bezkształtnego tworzywa kultury lub też egzystencjalnego zarysu, projektu, źródła dynamiki, a więc czegoś, co dopiero ma być urzeczywistnione w wyniku rozwoju ludzkiej kultury i historii. W świetle naszkicowanej koncepcji natury ludzkiej rzecz ma się odwrotnie. Dzięki tkwiącej w człowieku fundamentalnej organizacji jego dynamicznych struktur i mocą jej praw człowiek two-

\footnotetext{
76 Antoine, Morale sans anthropologie, 10.
} 
rzy siebie, własną kulturę i historię. I prawidłowość tego rozwoju zależy w decydującej mierze od tego, czy dokonuje się on po linii praw uwarunkowanych naturą ludzką czy też im na przekór. Otwartość człowieka na rozwój nie jest przeto bezkresem i nieokreślonością, a tym mniej dowolnością; polega ona na ukazaniu perspektywy dążenia ukierunkowanego dynamiczną strukturą człowieka, integrującą w swych ramach elementarne składniki jego bytu i przekształcające je w mechanizm właściwego mu działania. Toteż natura człowieka jest nie tylko siłą twórczą, ale także sprawdzianem i regulatorem historii i kultury. Dlatego wolno mówić o wynaturzeniach historii i kultury (np. Oświęcim, Dachau).

b) Zródła specyfikacji aktu ludzkiego i absolutny charakter norm moralnych

Obszerniejszy wywód na temat natury ludzkiej jako podstawowej rozumowej zasady etyki seksualnej nie tylko naświetlił istotne cechy tego pojęcia, ale także przygotował najważniejsze przesłanki dla rozstrzygnięcia dwu pozostałych zagadnień. Jedno z nich dotyczy moralnych aspektów aktu ludzkiego, drugie natomiast porządkujących je norm. Pozostają one we wzajemnej zależności logicznej i bywają zazwyczaj traktowane łącznie. Okazją zaś do poruszenia tych spraw jest stanowisko, jakie wobec nich zajęli nasi aktualni dyskutanci, przede wszystkim Fr. Böckle.

Szukając przyczyn zakwestionowania norm moralności seksualnej w świecie współczesnym dochodzi on do wniosku, że jednym z głównych powodów jest niewystarczające umotywowanie tej moralności ze strony Kościoła, oczywiście katolickiego. Przy uzasadnianiu głoszonych przez siebie norm posługuje się on do dziś scholastyczną teorią aktu wewnętrznie dobrego względnie złego. W rozumowaniu tym jednak kryje się zdaniem Bc̈cklego - wielkie uproszczenie problemu: porządek moralny zostaje utożsamiony $\mathrm{z}$ porządkiem bytu, co prowadzi w dalszej konsekwencji do nieuprawnionego absolutyzowania norm moralnych i do ich nieprzydatności w praktyce życia. Wobec tego autor proponuje teologiczną metodę uzasadniania norm, którą inni autorzy określają jako „,pragmatyczną" 77. Polega ona na rozpatrzeniu sytuacji w świetle różnych określających ją wartości, aby w wyniku tego obrachunku ustalić, która $\mathrm{z}$ nich $\mathrm{w}$ danym układzie jest najważniejsza i stwarza tym samym podstawę do sformułowania obowiązującej normy postępowania ${ }^{78}$.

Istotny sens postawionego przez Böcklego zarzutu, od którego zależy logiczna wartość wszystkich jego dalszych twierdzeń, wyraża się w zda-

77 Antoine, Morale sans anthropologie, 35.

78 Böckle, L'Église et la sexualité, „Concilium”, 100 (1975) 140-142. 
niu, że teoria aktu wewnętrznie dobrego względnie złego implikuje w sobie swoisty „błąd naturalistyczny”: wartość moralną i odpowiednią normę utożsamia ona $z$ prawidłowością „bytu”, czyli fizycznej struktury aktu. Czy jest to obiektywne przedstawienie rzeczy? Znowu daje dużo do myślenia znamienne przemilczenie ze strony Böcklego i sekundujących mu autorów. Dotyczy ono sprawy, o której łatwo można się przekonać zaglądnąwszy do jakiegokolwiek podręcznika tradycyjnej etyki tomistycznej. Ilekroć omawia się tam zagadnienie, aktu wewnętrznie dobrego względnie złego, wprowadza się zawsze rozróżnienie między jego aspektem fizycznym (,przedmiot materialny" - obiectum materiale) i aspektem formalnym (,przedmiot formalny" - obiectum formale). Rozróżnienie to stwierdza, że w akcie ludzkim czymś innym jest jego „,strona” czy „budowa” fizyczna, inaczej ,bytowa”, a czymś innym jego "strona" formalna, czyli wartość moralna. Tylko ta ostatnia włącza akt ludzki w porządek moralny, czyni to zaś na podstawie wewnętrznego związku tegoż aktu z odpowiednim dobrem moralnym, zwanym dziś coraz powszechniej obiektywną „wartością moralną", dawniej zaś częściej „dobrem godziwym” (bonum honestum). Uznanie ostrej granicy między porządkiem fizycznym a porządkiem moralnym jest tu zupełnie widoczne. A zatem zarzut Böcklego trafia w pustkę.

Te sumaryczne uwagi wystarczają, aby wykazać, jak dalece obraz doktryny tradycyjnej w ujęciu Böcklego odbiega od faktycznego stanu rzeczy. Czym tłumaczyć ten dziwny brak troski o rzetelną informację w referowaniu cudzych poglądów ze strony wybitnego skądinąd autora? Pozostawiając odpowiedź na to pytanie domyślności czytelnika należy z kolei zastanowić się nad wysuniętą przez Böcklego propozycją „,teleologicznej" drogi uzasadniania norm moralnych. Koncepcji tej z konieczności (inaczej przeciwstawienie się Böcklego teorii tradycyjnej traciłoby sens) towarzyszy założenie, że żadnemu działaniu nie odpowiada jedna, niezmienna wartość moralna, która od wewnątrz określa jego moralną jakość dobra lub zła, tak jak to przyjmuje koncepcja tradycyjna. Racją, która za tym przemawia, jest zdaniem wielu autorów fakt znacznego zróżnicowania sądów, w których dokonujemy moralnej oceny naszego postępowania. A zatem moralna ocena poszczególnych aktów opiera się, jak stwierdza Böckle, ostatecznie na wykryciu związku zachodzącego między danym działaniem a wartością uznaną przez podmiot działający w danym kontekście za najważniejszą i obowiązującą. Skoro jednak przyjęło się wewnętrzną nieokreśloność aktów ludzkich, w takim razie nie można zaprzeczyć, że odnoszenie tych czy innych wartości do danego aktu jest kwestią wyboru ze strony samego podmiotu, a zatem w roli wartości moralnych mogą wystąpić tak̇̇e wartości użytecznościowe lub przyjemnościowe, jeżeli podmiot działania dla jakichś od siebie zależ- 
nych racji uzna je za moralnie wartościowe. Ruchomość czynników specyfikujących moralną treść naszego działania powoduje, że moralnym staje się każde działanie, jeżeli tylko będzie odpowiadało temu, czego się domaga interes i własne upodobania jednostki, bądź też interes i upodobania określonych zbiorowości. Böckle dopatruje się w takim postawieniu sprawy urzeczywistnienia postulatu „realistycznego" traktowania moralnych problemów pod kątem charakterystycznej dla człowieka zmienności jego indywidualnych i historycznych sytuacji. Czy rzeczywiście chodzi tu o "realizm” etyczny, czy o coś innego, o tym się za chwile przekonamy.

Koncepcja teleologicznej specyfikacji aktu ludzkiego ma u Böcklego głębszą podbudowę filozoficzną w postaci egzystencjalistycznych i historycystycznych założeń antropologieznych, których pierwsze źródła tkwią, jak już tego dowiodły rozważania nad naturą ludzką, w teoriopoznawezych założeniach empirycystycznych. W urobionym na takich podstawach filozoficznych obrazie człowieka i jego działania akt ludzki przeobraża się w strukturę u samych podstaw równie zmienną i plastyczną, jak struktura samego człowieka. Przesunięcie punktu ciężkości jego moralnej specyfikacji w stronę kryteriów zewnętrznych jest tylko wyciagnięciem logicznych wniosków zawartych w treści wcześniejszych przesłanek ogólnofilozoficznych. Ich zaś końcową konsekwencją jest przyjęcie zasady, że w całokształcie postępowania człowieka nie ma ,,absolutnych", czyli powszechnych i niezmiennych norm moralnych (poza nielicznymi, dla etyki seksualnej nieistotnymi, wyjątkami). Normy moralne są historycznie uwarunkowane i zmienne.

Jak widać, sytuacja w zagađnieniu moralnej specyfikacji aktu ludzkiego i charakteru norm moralnych przedstawia się w koncepcji Böcklego zupełnie analogicznie do sytuacji, jaką stwierdziliśmy w problemie natury ludzkiej. Tezy etyczne swoje uzasadnienie znajdują w fakcie, że w wartościowaniach moralnych aktów ludzkich występują elementy zmienne, a ich ostateczną motywacją jest odpowiedni obraz filozoficzny człowieka i jego działania. W związku z tym ocena krytyczna propozycjı tego autora zostanie oparta na tym samym schemacie, jaki został zastosowany w wywodach poprzedniego punktu rozważań. Najpierw zostanie zakwestionowany wniosek Böcklego, że z faktu zróżnicowania sądów ludzkich na temat moralnej wartości ludzkiego postępowania wynika podstawowa nieokreśloność moralna tychże aktów, później zaś zamiast dyskusji z filozoficzną podbudową tej tezy zostanie przedstawiony w ogólnych zarysach wywód na temat tradycyjnej koncepsji wyznaczników specyfikujących moralnie akt ludzki.

Teza Böcklego o braku wewnętrznej określoności moralnej w strukturze aktu ludzkiego ma przeciwko sobie racje wzięte $z$ tego samego do- 
świadczenia moralnego, do którego się odwołuje. Zróżnicowanie sądów moralnych $\mathrm{w}$ dziedzinie wartościowania postępków ludzkich nie ulega wątpliwości, ale nie można zapominać, że zróżnicowanie to ma jednak swoje granice. Jest bowiem również rzeczą pewną, że mimo wszystko zachodzi w tej samej dziedzinie pewna fundamentalna jednolitość wartościowań (powszechnie się uważa, że doshowanie wierności, uszanowanie rodziców czy przestrzeganie sprawiedliwości jest czymś dobrym, postępowanie przeciwne - czymś złym). Jednolitość ta domaga się wyjaśnienia $\mathrm{w}$ postaci jakichś stałych i niezmiennych czynników określających moralną wartość tych działań, z czego znowu wynikają równie stałe i niezmienne formy postępowania.

$\mathrm{Na}$ temat koncepcji Böcklego to jeszcze powiedzieć można, że jest ona tylko pewną odmianą utylitarystyeznego poglądu na źródła moralności aktów ludzkich. Sprowadza się bowiem tylko do zastąpienia pojecia skutków działania przez pojęcie wartości. Podstawowe założenie o wewnętrznej nieokreśloności aktów ludzkich pozostaje to samo, w czym się zawiera konsekwencja, że ostatezznie sam podmiot de乞yduje o moralnej wartości swojego postępku dokonując wyboru wartości przez siebie uznanej za najważniejszą w danej sytuacji. Trudno nie dostrzes, że formuła ta zawiera w sobie wyraźne zalążki subiektywizmu i arbitralności w podejmowaniu decyzji moralnych ze strony działających podmiotów. Odwołanie się do najwyższych ideałów moralnych miłości, sprawiedliwości czy godności człowieka nie stwarza skuteıznej zapory przeciwko temu niebezpieczeństwu, gdyż w założeniu wewnętrznej nieokreśloności moralnej aktów ludzkich wszystkie motywy i cele działania za.wyjątkiem krańcowo niezgodnych z podstawowymi intuicjami moralnymi dadzą się odnieść do tych ideałów i przy ich pomocy usprawiedliwić. Radykalna elastyczność tych kwalifikacji przekształca się w końcu w etykę oportunizmu i kompromisu, która zatraca zrozumienie specyficznej natury porządku moralnego. W gruncie rzeczy niesie ze sobą jego degradację, gdyż czyni go przedmiotem sytuacyjnych przetargów i wyceny, po której stronie znajdzie się suma ,teleologicznie” lub ,pragmatycznie" wyważonych dóbr. Zaciera się w ten sposób linia graniczna między tym, co w sferze działania jest moralne, a co niemoralne, wtedy wszystko może stać się „,moralne”, co z kolei otwiera furtkę do kwalifikowania jako „moralne” tego, co jest dyktowane pospolitym utylitarnym interesem. Jest to $\mathrm{w}$ sobie błędne i prowadzi do licznych nadużyć. Jakich bowiem zbrodni nie popełniono w imię dobra narodu lub państwa!

Pozytywnym naświetleniem wypowiedzianych sądów będzie przypomnienie przewodnich idei tradycyjnej teorii na temat wyznaczników moralnej określoności aktów ludzkich. 
Etyka chrześcijańska wychodzi ze stwierdzenia, że doświadczenie moralne ukazuje akt ludzki jako dynamiczną całość psychofizyczną o budowie bardzo złożonej i różnorodnej. Jednakowoż intelekt ludzki dzięki swym racjonalnym zdolnościom poznawczym wykrywa w tej rzeczywistości nie tylko elementy konkretne, zmienne, zwane w języku tomistycznym „okolicznościami” aktu, ale również jego istotową strukturę stanowiącą stały i niezmienny czynnik budowy aktu. Ta istotowa struktura aktu ludzkiego utożsamia się $\mathrm{z}$ właściwą temu aktowi celowością, mocą której akt zmierza do urzeczywistnienia jednego skutku $\mathrm{w}$ tej celowości zawartego i ją wewnętrznie organizującego. Zwie się „przedmiotem” aktu albo też ,,celem czynności”, gdyż osadzony w samym centrum aktu stanowi konieczny przedmiot zamierzenia (chcenia) ze strony podmiotu decydującego się spełnić ten akt. Miejsce, jakie przedmiot aktu, inaczej cel czynności, zajmuje w wewnętrznej dynamice aktu, sprawia, że pełni on rolę podstawowego wyznacznika moralnej jakości całego aktu. Czyni to jednak nie siłą swej fizycznej rzeczywistości, o ile wyraża ona jakąś prawidłowość bytu, ale tylko w tym stopniu, ile pozostaje $\mathrm{w}$ odpowiednim związku z określoną wartością moralną, która jest ostatecznym źródłem właściwego danemu aktowi moralnego dobra.

Jeżeli zaś dany przedmiot nie wykazuje żadnego stałego związku z odpowiednią wartością, wówczas przedmiot, a konsekwentnie i cały akt, jest moralnie nieokreślony, czyli „obojętny”. Jego moralna jakość jest wynikiem przyporządkowania go jakiejkolwiek wartości, choćby utylitarnej, z uwzględnieniem wszystkich wchodzących w grę warunków działania. Zmienność tych wartości sprawia, że cały akt jest moralnie względny, co znaczy, że nie ma stałej, wewnętrznie z nim związanej jakości moralnej. Jego wewnętrzna obojętność sprawia, że właściwe mu dobro jest pochodzenia zewnętrznego. Są to więc akty zewnętrznie dobre lub złe (np. uprawianie turystyki).

Ale nie jest to jedyna możliwość. Istnieje bowiem także kategoria aktów, których przedmiot pozostaje w stałym, wewnętrznym związku z odpowiadającą mu wartością, czyli dobrem moralnym. A wtedy dobro (względnie zło) działania nie dochodzi już doń ,z zewnątrz”, od podmiotu kierującego się własnym rozeznaniem, co mu w danej sytuacji odpowiada. Wręcz przeciwnie, dobro (ewentualnie zło) działania zakorzenione jest w samym jego wnętrzu, w celowości, określającej dynamiczną treść aktu, czyli sięga niejako do dna jej rzeczywistości i czyni go dzięki temu nieodwracalnie ,dobrym” lub ,złym". Ponieważ przedmiot jest w całym tego słowa znaczeniu wewnętrznym czynnikiem aktu, a związek z określoną wartością jest tu również wewnętrzny, przeto mamy $\mathrm{w}$ takim wypadku do czynienia $\mathrm{z}$ aktem wewnętrznie dobrym bądź też 
wewnętrznie złym. Wartość tkwiąca $\mathrm{w}$ moralnej strukturze przedmiotı może mieć zakres aksjologiczny niczym nie ograniczony i wtedy zachodzi akt wewnętrznie dobry lub zły absolutnie (np. krzywoprzysięstwo, cudzołóstwo), ale może też podlegać odpowiedniemu zacieśnieniu, wskutek czego cały akt będzie aktem wewnętrznie dobrym lub złym restryktywnie (np. kłamstwo) ${ }^{79}$.

Dwojakiej kategorii aktów: zewnętrznie dobrych lub złych oraz wewnętrznie dobrych lub złych odpowiadają znowu wypływające z tych źródeł normy moralne. Stosownie do wskazanego podziału akty zewnętrznie dobre lub złe stwarzają podstawą do formułowania ocen i norm o charakterze względnym, sytuacyjnym, wyrażających w najlepszym razie tylko indukcyjne uogólnione normy postępowania. Natomiast na podstawie aktów wewnętrznie dobrych ewentualnie wewnętrznie złych tworzą się oceny i normy zawsze ważne, niezmienne, czyli absolutne ( $\mathrm{np}$. nie cudzołóż, nie popełniaj krzywoprzysięstwa). Wśród tych ostatnich zachodzi jeszcze różnica między normami pozytywnymi, czyli nakazami moralnymi, a normami negatywnymi, czyli zakazami moralnymi. Pierwsze są absolutne w swej normatywnej treści jako imperatywy zawsze ważne, ale ich stosowanie wymaga uwzględnienia konkretnych warunków działania (np. przychodź bliźnim z pomocą). W tym znaczeniu można o nich powiedzieć, że są absolutne warunkowo, zależnie od sytuacji i okoliczności. Inaczej ma się rzecz z normami negatywnymi. Obowiązują one zarówno w swej normatywnej treści, jak i w stosowaniu ,zawsze i wszędzie", co sprawia, że nie dopuszezają one sytuacyjnie uwarunkowanych wyjątków. Są to normy bezwarunkowe. Jedynie w wypadku norm odnoszących się do aktów wewnętrznie złych restryktywnie ma miejsce ograniczenie ich obowiązującego charakteru odnośnie do zawartego $\mathrm{w}$ ich treści ograniczenia, czyli restrykcji. Nie przestając byćc normami bezwarunkowymi stanowią osobną grupę norm bezwarunkowych restryktywnie. Tak ma się rzecz np. z zakazem kłamstwa, który nie odnosi się do sytuacji słusznej obrony sekretu ${ }^{80}$.

W świetle poczynionych uściśleń widać, że w sporze między Böcklem i podobnie jak on myślącymi autorami a tradycyjną etyką tomistyczną nie chodzi bynajmniej o utożsamienie świata wartości ze światem bytów przy interpretowaniu źródeł moralnej specyfikacji aktów ludzkich i obowiązującego charakteru wypływających stąd norm moralnych. Etyka tomistyczna nie popełnia tego błędu w tym samym stopniu co i Böckle. Co więcej, nie chodzi nawet o to, czy wśród różnych kategorii aktów ludzkich i odpowiadających im norm znajdują się akty dobre lub złe

79 Slipko, Zarys etyki ogólnej, 197; por. 127-142, 196-198.

80 Por. T. Slipko, Zagadnienie godziwej obrony sekretu, Warszawa, 1968, 87-226. 
zewnętrznie oraz normy względne, uwarunkowane sytuacyjnie lub historycznie. Istotę toczącego się sporu stanowi głównie pytanie, czy wszystkie działania ludzkie są zewnętrznie dobre lub złe i czy wszystkie normy mają charakter względny, czy też obok aktów zewnętrznie dobrych ewentualnie złych oraz norm względnych, sytuacyjnie lub historycznie ważnych, można ustalić także kategorię aktów wewnętrznie dobrych bądź złych, jak również kategorię norm absolutnych, zawsze ważnych (we wskazanym uprzednio zasięgu). Przytoczone racje, zarówno te, które ukazują luki w rozumowaniu Böcklego, jak też te, które uzasadniają stanowisko tradycyjne, skłaniają do przyjęcia ostatecznego wniosku, że pojęcie aktu wewnętrznie dobrego ewentualnie złego oraz norm absolutnych jest filozoficznie uprawomocnione. W związku z tym należy je uznać za nadal obowiązujące zasady rozumowe, do których musimy się odwoływać przy budowaniu normatywnej etyki seksualnej. Nie przesądza to wprawdzie kwestii, jaką postać przybierze ta etyka. $\mathrm{Na}$ razie bowiem zostały tylko ustalone narzędzia teoretyczne, przy pomocy których będą rozstrzygane jej podstawowe problemy.

\section{PRINCIPES MÉTHODOLOGIQUES DE LA ÉTHIQUE SEXUELLE}

\section{R E S U M E}

Aujourd'hui, quand on parle de la morale sexuelle, ce qui revient le plus souvent dans les problèmes, c'est le refus radical de la morale et de la théologie chrétienne. Parmi les contestataires, il y a non seulement les tenants de la morale laique mais aussi des catholiques nombreux, philosophes ou théologiens comme J. Davis. S. Pfürtner, Ph. Schmitz, Fr. Böckle, Ch. Antoine, C. E. Burran. Leurs critiques s'€n prennent aux commandements et aux défenses qui obligent au nom de la doctrine chrétienne traditionnelle, mais elles attaquent aussi les principes anthropologiques et finalement les principes méthodologiques. Mais il est vrai que le poids de ce genre de critiques ne va pas toujours de pair avec les raisons profondes et positives. Ce sont en général des clichés qui expriment plutôt les convictions subjectives des auteurs que des théories objectivement fondées. Mais même la, il faut examiner la problématique qu'elles comportent ou tout moins la signalent en passant. Il s'agit surtout des principes méthodologiques de l'éthique sexuelle et à ce titre elles font l'objet principal de cette étude.

En premier lieu, nous considérerons la question métaéthique de la morale sexuelle car ses critiques atteignent les principes mêmes de sa raison d'être comme science philosophique normative. Elle a été soulevée par les auteurs qui ont mis en doute le statut scientifique de l'éthique sexuelle et l'autorité de ses jugements et de ses normes. Certaines estiment que l'etablissement des normes relève des „,sciences”, ceux-là s'appuient sur les données ,positives” et ,verifiées” par l'expérience. D'autres sont hautement persuadés que l'éthique et pas la science a poùr 
vocation de définir les règles de la morale mais, hélas, elle le fait sous la pression des besoins de la vie et à partir d'opinions subjectives idéologiques, par suite irrationnellement et donc scientifiquement sans valeur.

Après avoir analysé chacune de ces deux conceptions l'auteur a donné leurs sources philosophiques; elles peuvent se ramener aux théories néopositivistes et émotionalistes. On peut en conclure que l'opposition métaétique entre l'éthique chrétienne traditionnelle et la contestation moderne n'est pas (comme suggerent les auteurs) une opposition entre la métaphysique et les acquisitions des sciences expérimentales, mais une opposition entre deux philosophies et leurs théories de la connaissance: realistico-rationnelle et empirico-sceptique. A cette lumière, apparaissent les bases insuffisantes sur lesquelles sont fondées les critiques faites à l'éthique chrétienne traditionnelle normative: conception trop unilatérale de ,expérience" limitée surtout à l'expérience externe valable pour le monde phénoménal et de ce fait conditionnée par une perspective étriquée du concept de „science" et de valeur théorique des affirmations scientifiques. C'est à ces prises de position philosophique inadéquate que l'on oppose la philosophie chrétienne traditionnelle. Elle s'appuie sur la thèse du caractère objectif de la connaissance intellectuelle (concepts universels), grâce à quoi, cette philosophie peut bâtir des concepts adéquats de ,science" et de ,philosophie" et des critères de preuve et d'objectivité de la connaissance humaine. Admettant la spécifité et l'autonomie de ces deux domaines de la connaissance humaine, elle peut se permettre de justifier à la fois la rationalité de la philosophie et de l'éthique sexuelle.

Dans la discussion moderne, à coté des principes métaéthiques de l'éthique sexuelle, on a aussi remis en question ses sources, rurtout les principes rationnels de l'éthique chrétienne traditionnelle. Il s'agit du concept de ",nature humaine" et de „droit naturel” et du concept ,d'acte intrinsèquement mauvais”. Justement sur ces deux concepts repose l'éthique chrétienne.

Les critiques visant la conception traditionnelle de nature humaine revêtent chez chaque auteur des formes que l'on peut ramener à la formulation générale que voici: il n'y a pas de nature commune aux hommes et constante telle qu'elle puisse être source et principe du droit objectif et absolu. La nature et la morale humaine, y compris la morale sexuelle, se constituent au cours d'événements en accord avec les conventions historiques conditionnées par la société, aussi sont-elles changentes. Les concepts traditionnels de ,nature” et de ,droit naturel” sont métaphysiques, sans contenu et des abstractions théoriques inutilisables.

Il en est de même de la théorie traditionnelle des actes intrinsèquement mauvais. Nombre d'auteurs qui critiquent ce concept disent que l'éthique chrétienne simplifie par trop la question. Elle fait reposer l'acte humain bon et mauvais sur ,l'essence” ou ,nature de l'acte” et identifie par là morale et l'être, ce qui rend la morale abstraite et les normes normatives absolument formelles. C'est pourquoi il faut remplacer le concept de l'acte intrinsèquement mauvais par des critères beaucoup plus souples de bien et de mal moral afin d'élaborer par eux une méthode capable de fonder les normes de morale convaincantes et répondantes à la mentalité de l'homme contemporain.

Le résultat définitif que propose la refonte du concept de nature humaine et de l'ácte intrinsèquement mauvais est d'ouvrir en morale sexuelle la voie à une interprétation des appréciations et des normes dans le sens de ce qui est permissif en sexualité. Ainsi cela conduit à donner une immense portée à cette problématique rendue valable. Ainsi elle est traitée dans son entier et dans un contexte de réflexions générales sur le fondement méthodologique de l'éthique sexuelle. 
A partir de cette ligne de pensée, l'auteur esquisse d'abord les concepts élémentaires de l'objet, des sources et de la méthode de l'éthique sexuelle. Il s'efforce de montrer que l'objet de l'éthique sexuelle se compose de trois sortes d'éléments: le premier comprend les actes ou comportements sexuels, le deuxième les intuitions et les convictions morales des gens, ce qu'on appelle communément la morale sexuelle, et enfin le troisième, l'aspect normatif de cette morale qui fixe la tâche théorique propre à cette éthique. Cette tâche consiste d'abord à établir le sens, les sources de valeurs morales et des impératifs correspondants au comportement sexuel humain, ensuite définit ce qui est moralement bon et mauvais, ce que l'on doit faire ou ne pas faire, autrement dit l'éthique formule les appréciations et les normes morales. Il fait ressortir la différence entre les sciences particulières de la sexologie et de l'éthique sexuelle. Il apparaît que la méthodologie des sciences particulières ne peut leur permettre de créer les règles, que cette création est de la compétence de l'éthique sexuelle. Cette constatation révèle de plus d'où viennent les erreurs des auteurs qui veulent charger les sciences particulières ou même la pratique morale des gens de formuler les règles du comportement sexuel humain

Quand il caractérise le concept d'expérience morale, l'auteur attire l'attention sur la portée des sciences sexologiques particulières (anatomie, physiologie, psychologie) en vue des considérations philosophiques et éthiques, mais souligne également leur différence fondamentale par rapport au sens stricte de "l'expérience éthique". Celle-ci consiste en effet dans la prise de conscience et dans l'objectivisation orale ou écrite de propres états conscients qui ont comme objets des convictions et des idéaux normatifs du comportement sexuel. Elargissant son sujet, l'auteur expose plus amplement les résultats de l'éthnologie de la morale sexuelle et fait la somme des déductions des plus importantes pour les considérations normatives. Il souligne que les civilisations primitives ont déjà deux types de morale: celui qui permet les rapports sexuels avant le mariage et celui plus stricte qui les interdit. Donc l'idéal de pureté avant le mariage est plus ancien que le christianisme et le permissif sexuel n'est point une acquisition de l'homme moderne. On voit aussi que la conscience morale humaine a la conviction inconsciente que l'homme peut maîtriser l'impulsion sexuelle et en même temps indique la tendance à acquérir une certaine liberté sexuelle. A cause de cela ce n'est pas l'expérience mais une vision complète de l'homme et les principes que la raison en tire peuvent résoudre le problème lequel de ces deux courants est conforme à la véritable (authentique) éthique sexuelle humaine. Dans l'éthique chrétienne traditionnelle, ces principes s'identifient avec les concepts de nature humaine, de droit naturel et d'acte intrinsèquement mauvais. C'est contre eux que vont surtout les objections, aussi devraient-elles devenir l'objet d'une analyse philosophique et morale plus attentive.

L'auteur en critiquant ces objections a montré qu'elles decoulent du relativisme et historicisme éthiques qui reposent définitivement sur l'empiricisme philosophique dont l'inadéquation théorique a été déja dénoncé. Cette discussion montre (comme dans le problème métaétique) qu'il ne s'agit pas de faire accepter à la philosophie chrétienne les acquisitions de la nouvelle anthropologie philosophique et des sciences expérimentales modernes ni d'une indispensable adaptation a notre époque de la doctrine éthique traditionnelle. Il s'agit en réalité de placer l'éthique chrétienne sur la voie du relativisme utilitariste et du subjectivisme éthique, depuis longtemps reçu par la morale laĩque et que ces auteurs ont à présent rénandu dans le christianisme.

Certes la tâche propre de cette étude était de souligner et de mettre en évidence le traits essentiels de la conception chrétienne de nature humaine et d'acte intrin- 
sèquement mauvais. L'auteur a souligné l'importance qu'y a la thèse de la valeur objective des concepts universels par lesquels l'intellect humain peut percevoir les structures essentielles dans les êtres concrets et changeants. Ainsi le concept de nature humaine et d'acte humain ne veut pas dire que dans la structure de l'homme et de ses actes il n'y a pas des éléments muables et historiquement conditionnés. Par contre il s'agit d'affirmer qu'à coté de ces éléments ilya dans l'homme et ses actes une réalité objective et stable; elle s'identifie avec le contenu humain et la finalité interne des actes humains; elle constitue aussi la source et la force créatrice où s'origine l'univers des valeurs stables et des impératifs de la morale, qui définissent le sens moral fondamental des catégories des actes correspondants à ces impératifs. Le concept de nature humaine et d'essence des actes humaiains a donc dans l'éthique chrétienne un sens foncièrement éthique. Il exprime le contenu de l'homme comme sujet moral et ainsi sert de fondement pour définir les règles importantes, stables et universel de l'agir humain. Si on y touche, les actes sont alors marqués par l'acte intrinsèquement mauvais. Une analyse plus poussée du monde des valeurs conduit cependant à la conclusion que les actes intrinsèquement mauvais ne sont pas tous de la même manière intrinsèquement mauvais. Certains sont absolument mauvais, sans limite ou mauvais intrinsèquement et absolument, d'autres ont un domaine axiologique d'importance limitée grâce à une restriction dont le contenu est rigoureusement défini et restreint. Ce sont des actes intrinsèquement mauvais, mais d'une manière restrictive.

Une éthique sexuelle qui repose sur de telles prémises méthodologiques peut permetre de bâtir un système des normes-impératives qui indique la frontière morale du comportement humain. Dans la mesure où le comportement sexuel humain, grâce à sa finalité intrinsèque sert directivement à eveiller la plus haute valeur de la vie personnelle humaine, ils ont un caractère absolu, donc stable parce que la personne dans son existence a droit à une dignité grande et intégrale. Mais si le comportement sexuel humain ainsi défini n'est pas directement lié à l'éveil de cette vie, ils seront appréciés moralement de facon variable, au gré des cinconstances. 